\title{
Maritime-archaeological investigations of the Hanseatic harbour at Avaldsnes
}

\author{
ENDRE ELVESTAD AND ARNFRID OPEDAL
}

Elvestad, E., Opedal, A. 2019. Maritime-archaeological investigations of the Hanseatic harbour at Avaldsnes. AmS-Skrifter 27, 217-236, Stavanger. ISSN 0800-0816, ISBN 978-82-7760-183-0.

Investigations of the medieval harbour at the important royal manor of Avaldsnes, south-west Norway, revealed extensive underwater cultural layers and structures like ballast heaps and jetty foundations from the thirteenth until the early sixteenth century. The finds cover a large area and the conditions for preservation of the archaeological material is excellent. A waiting harbour at this strategic site along the fairway to Bergen probably got new functions and became the arena for intense activity during a 100-year period c. 1350-1450. The site known from written sources as Notau was most likely part of the same economic network as Bergen with ties to Hanseatic cities like Lübeck and Danzig. The pottery found on the sea bottom reveals an even wider range of international connections. The results have implications for the relationship between the Norwegian king and the Hanse and the Hanse's activity outside of the medieval towns. The site is largely undisturbed by modern development and thus very well suited for future research.

Endre Elvestad, Brettlandsgata 45, N-4009, STAVANGER, NORWAY. Email: endre.elvestad@icloud.com Arnfrid Opedal, Midtre Suldalsgt. 12, N-4014, STAVANGER, NORWAY. Email: arnfrid.opedal@lyse.net

Keywords: medieval harbour, royal manor, Hanse, Avaldsnes, maritime archaeology

\section{Introduction}

Avaldsnes is a small village on the east side of the island of Karmøy in the northern part of Rogaland county in south-west Norway. To the west of Karmøy is the North Sea with a coastline that is quite dangerous in heavy weather as it offers no shelter against the waves and no natural harbours for bigger ships. To the east of Karmøy is the narrow Karmsund, meaning 'the sheltered sound'. It is about $32 \mathrm{~km}$ long and is one of the busy sea routes in Norway, forming the southern length of the route along the west Norwegian coast leading to Bergen and then to North Norway. In the Viking Age and medieval period it was known as Nordvegen (the North Way) and in Dutch cartography of the sixteenth and seventeenth centuries as Dat Liet van Bergen (the fairway to Bergen). South and north of Karmsund there are exposed coastal stretches unprotected from the sea. To avoid these rough waters, small vessels were hauled over land from one fjord to another to the east of Karmøy, but this was not an option for heavy cargo ships. Avaldsnes and the small islands to the south of the headland offered excellent anchorages, and are marked on sea maps from the sixteenth century onwards. In modern times, after the introduction of steam ships and motor-driven vessels, these anchorages lost most of their importance, but they are still used, mostly by small boats and yachts (Fig. 1).

In the Middle Ages and Early Modern period the sailing routes from the Continent and Great Britain usually met the Norwegian coast to the south of Karmøy. Sailing instructions tell how to reach Karmsund. Sailors approaching the sound could use the distinctive mountain of Boknafjellet on the island of Bokn to find the southern entrance. Avaldsnes is located at the most strategic point in Karmsund, forming a headland that narrows the sound and causes strong tidal currents. They are so strong to the north of Avaldsnes that it is impossible for rowing or sailing ships to pass until the tide turns. With continuous northern winds, the currents flow constantly southward which could force ships to wait for considerable periods. The narrow sound with its strong currents made it easy to control the traffic through Karmsund from Avaldsnes, a fact known in prehistory. Impressive archaeological finds and ancient monuments from the Bronze Age and the Iron Age prove that those who controlled Avaldsnes belonged to an elite dominating a larger area and exercising 


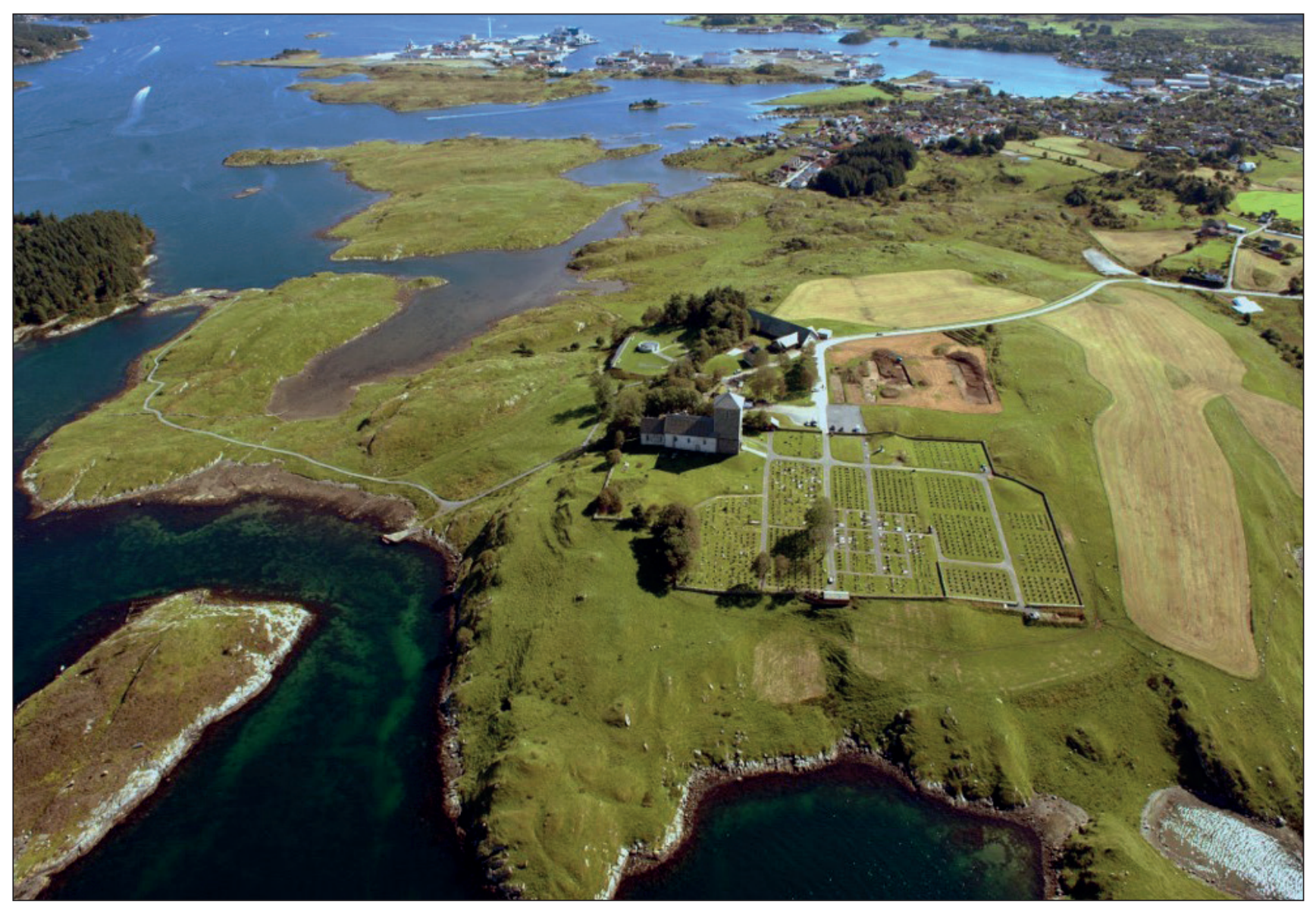

Fig. 1. Avaldsnes today, looking southwards. The medieval harbour is located in the upper left part between the islands (photo: KibMedia).

considerable political influence in the western part of Norway (Fig. 2).

Saga literature and medieval documents indicate that Avaldsnes was in the possession of the Norwegian kings as a royal estate. According to the sagas, Avaldsnes became one of Harald Hårfagre's (Harald the Fairhair, c. 852-933) most important residences after his victory in the battle of Hafrsfjord about 872. Harald Hårfagre himself is said to have been buried close to Karmsund, and in the area there is a concentration of prehistoric burials reflecting a royal status. ${ }^{1}$ Recently, a German silver coin minted between 1046 and 1056 was found at Avaldsnes. Such coins often turn up at royal manors where the exchange of goods took place. ${ }^{2}$ The further recent discovery of a stone hall at Avaldsnes of $c .1300$ adds significantly to the knowledge of the royal manor in the High Middle Ages. This is the fourth medieval royal stone hall known to have existed in Norway, the others being situated in Bergen, Oslo and Tønsberg. ${ }^{3}$ Several royal letters were written at Avaldsnes in the late thirteenth and fourteenth centuries and show that the place had royal administrative functions. When the jurisdiction area of the Gulathing, comprising the western part of Norway, was divided into two around 1300, Avaldsnes became the centre of the southern part. The building of the large Gothic stone church at Avaldsnes dedicated to St. Olav started around the middle of the thirteenth century in the reign of king Håkon Håkonsson and finished probably about half a century later. In 1308 the church became one of the fourteen royal chapels which the Pope allowed King Olav V Magnusson to establish. The church at Avaldsnes was one of four collegiate churches with priests and clerks to staff a bureaucracy. The other three collegiate royal churches were in the towns of Bergen, Oslo and Tønsberg.

It was obviously not solely religious motives that led the king to organize the royal chapels. The fourteen chapels were located in seaports and at strategic places along important trading routes on the Norwegian coast leading to the Baltic, England and the Continent. The king needed people to handle trading transactions and to keep the accounts. Similar, so-called merchant churches are found in Continental Europe, often in connection with Hanseatic trading stations. Such churches, in addition to religious services, also provided safe storehouses for commodities and people with literary and mathematical competence. 


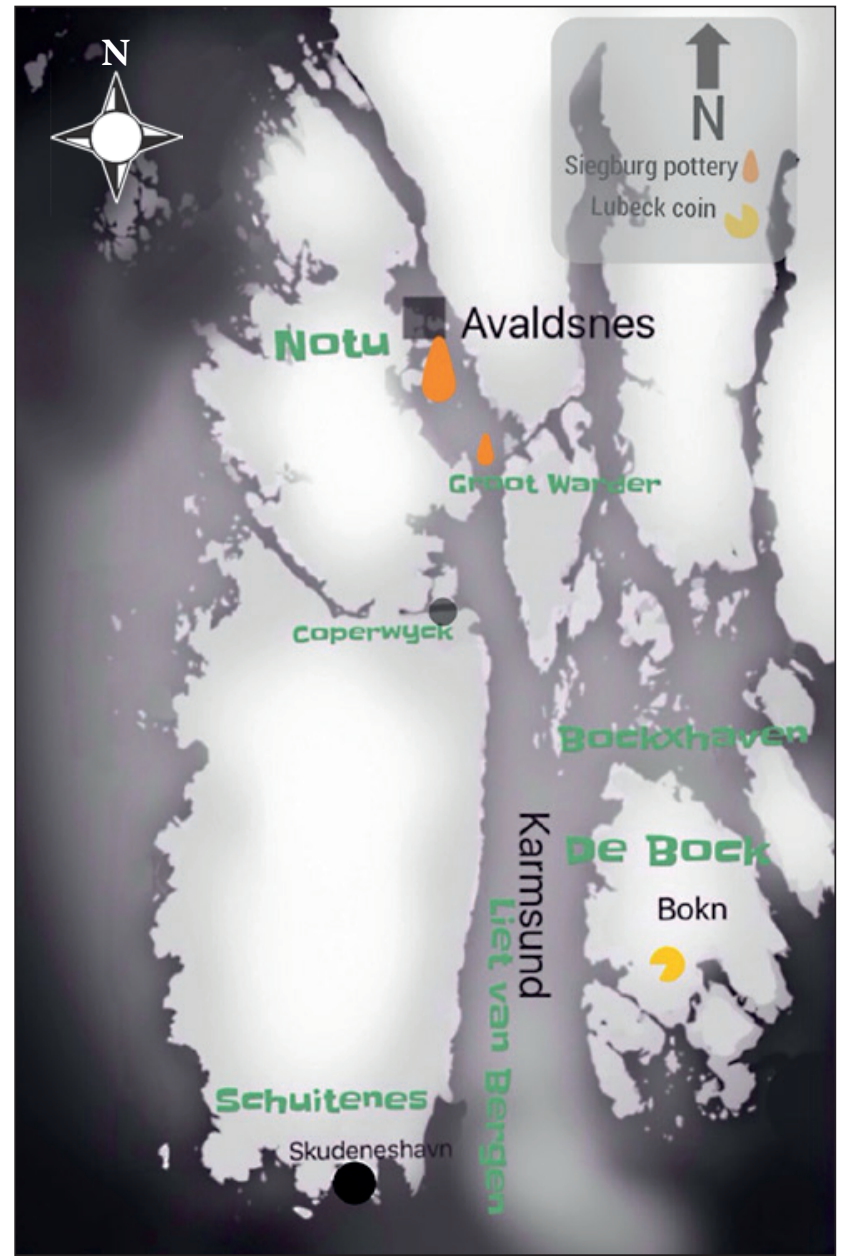

Fig. 2. Karmsund and place names mentioned in the text together with names from the Dutch map from 1663 and archaeological finds associated with the Hanse (illustration: Arnfrid Opedal). For the 1663 map see Fyllingsnes, this volume.

The fourteenth century is an important but elusive period in the history of Avaldsnes. After what appears to be significant royal investment here in the earliest part of the century, the juridical functions of the Gulathing were removed sometime between 1322 and 1351 to Stavanger further south. Hanseatic sailors burnt down the royal residence at Avaldsnes in 1368 during a conflict with the Danish-Norwegian king, but it was probably rebuilt, since King Håkon VI issued a decree here in July 1374. That is the last royal letter known to have been written at Avaldsnes and, from then on, the importance of the place gradually declined.

Nevertheless, in 1453 an important discussion between king Christian I and Henrik Kalteisen, archbishop of Nidaros, the Norwegian see, probably took place at Avaldsnes. ${ }^{4}$ During their meeting, their ships lay side by side, implying that there was no royal manor house. The status of Avaldsnes farm at this time had probably been reduced to a vicarage, a function it continued to serve until around the year 2000.

Documents from the fifteenth century of Hanseatic origin mention a place called Notau, evidently located somewhere along the coast of south-west Norway. The oldest source is a will of a Bergenfahrer written in Lübeck in 1425 , which contains a donation to building work at Notau. The final contemporary documentary evidence of the site of Notau is a letter written by a DanishNorwegian nobleman who in 1532 wanted to sell some fish to a ship from Danzig waiting in Notau. In the late sixteenth century, a foreigner residing in Bergen, probably of German origin (his name is unknown), wrote a manuscript called Die Nortsche Saw (The Norwegian Sow) where he claimed that the first Hanseatic Kontor in Norway was $z u$ Nothaw, but that it was later moved to Bergen because of pirates. ${ }^{5}$

Place-names at Avaldsnes with the element Nottå indicated that the site associated with the Hanse could have been situated here. For instance, two small anchorages between the small islands south of Avaldsnes were called Nore Nottå and Søre Nottå (North Nottå and South Nottå). The origin of the name Notau has been debated, but one possibility is that it might be a Germanification of Norse Nautey, meaning 'cattle island', the island where cattle graze. ${ }^{6}$ In historical times the islands in Karmsund belonging to the Avaldsnes farm were used as grazing ground for cattle and sheep. In addition to place-names, Dutch sea maps are important in locating Notau. These maps, the oldest one from 1588, place Notau on the northern part of Karmøy. Of special interest is a map from 1663 with the name Notu close to a church in the Avaldsnes area. ${ }^{7}$

Several small marine archaeological surveys were carried out close to the small islands south of the church at Avaldsnes in the late 1970s and in the 1980s. During these surveys divers also excavated two trenches in the narrow sound between the islands of Bukkøy and Fårøy (Fig. 3). They recorded cultural layers, including pottery, shoes and leather fragments, animal bones and also a shipwreck. A large proportion of these finds belonged to the period between 1600 and 1800 but, when this material was reassessed in 2000, what stood out was the number of whole or nearly whole jugs of Siegburg-type pottery from the fourteenth and the fifteenth century. ${ }^{8}$ Such pottery is a strong indication of Hanseatic presence. ${ }^{9}$ The reevaluation indicated that many of the Siegburg jugs were found at some distance from the shore, often $30-40 \mathrm{~m}$ away, which was the preferred place for anchored ships. To advance our understanding, further archaeological research, both in the sea and on land was required. 


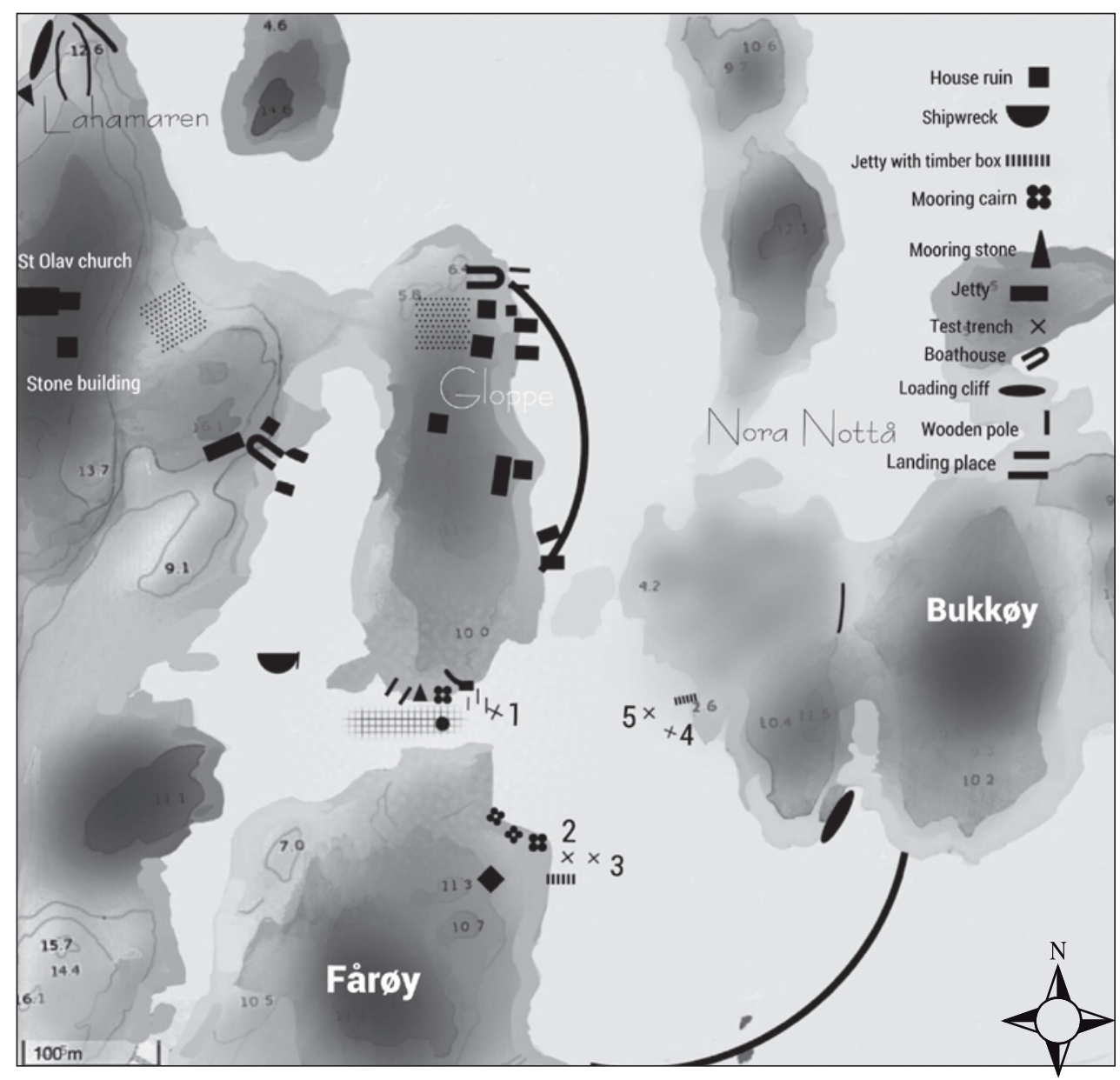

Fig. 3. The harbour area at Avaldsnes and finds referred to in the text (illustration: Arnfrid Opedal).

\section{Maritime archaeological investigations since 2000}

Archaeological surveys at Avaldsnes, both underwater and on land, were resumed in 2000 and continued intermittently until 2012. Small underwater test excavations took place in 2003, 2010 and 2012, and an excavation on land in 2011. ${ }^{10}$ The deep mud which covered the seabed in much of the harbour area proved to be a challenge for the underwater work. In the inner harbour the mud was up to $2.5 \mathrm{~m}$ deep, but it provided extraordinary conditions for the preservation of organic material. The majority of the information stems from extensive underwater surveys in the areas not covered with mud where archaeological material was visible on the seabed. In addition, a few test pits were excavated. These were small in scale, on average $1 \mathrm{~m}$ by $1 \mathrm{~m}$ and from $0.5 \mathrm{~m}$ to $1.5 \mathrm{~m}$ deep. The pits thus covered a very small part of the total area of finds.

The harbour consists of a central bay with two distinct parts, one inner and one outer, separated by a narrow sound. The sound is the main entrance to the inner harbour, but there is also a very shallow passage from the south (Fig. 3). The majority of the underwater surveys were undertaken in the sound and in the outer harbour. Very little work took place in the inner harbour due to the depth of the mud but, nonetheless, it is assumed that this was an important part of the medieval harbour. The main harbour area at Avaldsnes is surrounded with smaller bays where some further finds were also observed.

The remains furthest to the north were at a place named 'Lahamaren', close to St. Olav's church. The name is normally interpreted as an indicator of a loading site. ${ }^{11}$ Lahamaren is a steep cliff where three or four old roads converge. They seem to lead either in the direction of the church or further inland on the island. A stone, probably a pre-modern point for mooring, stands at the point where the roads meet above the cliff. Steep cliffs forming natural quays where roads meet often indicate places where ships could load heavy cargo. The presence of ballast beneath the cliff provides a further indication that it was used in this way. Possible ballast was also observed east of Lahamaren in the earlier surveys, but this has not been confirmed during the recent investigations.

A thin cultural layer with small fragments of possible medieval pottery, together with some slag and burnt bones was discovered in small testpits south-east of the church. These have to be treated with some reserve due 
Table 1. Dating of animal bones and wood from test pit 1 dug in the sea bed in the inner part of the outer bay close to the narrow sound.

\begin{tabular}{|l|l|l|c|c|}
\hline \multicolumn{1}{|c|}{ Lab. ID. } & \multicolumn{1}{|c|}{ Context } & \multicolumn{1}{c|}{ Material } & $\begin{array}{c}\text { 14C age } \\
\text { uncal. BP }\end{array}$ & Cal AD, 20 \\
\hline Beta-297534 & AV2A, layer 2, top, $20 \mathrm{~cm}$ below seabed & Humerus-cattle & $480 \pm 30 \mathrm{BP}$ & $1410-1450$ \\
\hline Beta-297535 & AV2B, layer 2, top, $20 \mathrm{~cm}$ below seabed & Vertebra - fish & $740 \pm 40 \mathrm{BP}$ & $1490-1660$ \\
\hline Beta-297538 & AV4, layer 2, bottom, $55 \mathrm{~cm}$ below seabed & Vertebra- cattle & $520 \pm 30 \mathrm{BP}$ & $1400-1440$ \\
\hline Beta-297532 & AV1A, layer 4, top, $70 \mathrm{~cm}$ below seabed & Tarsometatarsus- bird & $560 \pm 30 \mathrm{BP}$ & $\begin{array}{l}1310-1360, \\
1390-1430\end{array}$ \\
\hline Beta-297533 & AV1B, layer 4, top, $70 \mathrm{~cm}$ below seabed & Vertebra-fish & $1000 \pm 30 \mathrm{BP}$ & $1320-1430$ \\
\hline Beta- 297536 & AV3A, layer 4, bottom, $95 \mathrm{~cm}$ below seabed & Pelvis - pig & $550 \pm 30 \mathrm{BP}$ & $\begin{array}{l}1320-1350, \\
1390-1430\end{array}$ \\
\hline Beta- 297537 & AV3B, layer 4, bottom, $95 \mathrm{~cm}$ below seabed & Wood & $940 \pm 30 \mathrm{BP}$ & $1020-1170$ \\
\hline Beta- 297539 & AV5, layer 5, bottom, $135 \mathrm{~cm}$ below seabed & Gyttja & $1300 \pm 30 \mathrm{BP}$ & $669-770$ \\
\hline
\end{tabular}

to the very limited extent of the survey. ${ }^{12}$ The finds were made adjacent to an undated well, one of the few sources of water in the harbour area. An old road leads from the well to a concentration of ruined houses, a boathouse, two jetties and a number of unspecified remains in the inner part of the harbour. One of the houses clearly has two phases of occupation.

The deep mud on the seabed in the inner harbour made underwater survey very difficult, but one stray find of possible medieval pottery together with some cut wood were discovered here. Asbjørn Simonsen from the Museum of Archaeology in Stavanger, took a core sample in the inner bay for a sediment and botanical analysis together with material for C14 dates in $1978 .^{13}$ The layer of mud here was $1 \mathrm{~m}$ thick covering a former seabed consisting of sand, gravel and shells. The upper $50 \mathrm{~cm}$ of the organic layer contained fragments of charcoal which, according to Simonsen, was probably caused by an increased activity in the harbour. A new calibration dates this phase to c. AD 1300-1530).

A pile of stones was detected in the middle of the $36 \mathrm{~m}$ wide sound between Farøy and Gloppe at the depth of about $2 \mathrm{~m}$. Two similar piles of stone on the seabed in the outer harbour are interpreted as remains from timber caissons filled with stones and used as part of jetty foundations (Fig. 3), but the pile in the narrow sound was more ambiguous. It may have been the foundation for a bridge that crossed the sound. A rope of uncertain age was found which appeared to cross the sound. On the north side of the sound a road led to a jetty. It is a partially natural jetty made of rocks and improved with a flat cover of flagstones. Three wooden poles standing in the seabed were observed in this area during the investigations in the 1970s and 1980s. A mooring cairn and a mooring stone stand close to the jetty and this was a probable landing place for boats.

Gas coming up from the seabed had been observed in the sound during the earlier investigations, which may have been methane, perhaps originated from decaying organic material without access to oxygen, indicating that large amounts of such material were dumped here during a short time span. ${ }^{14}$ Test pit 1 was excavated near the outlet of the narrow sound at a depth of about $3 \mathrm{~m}$. This revealed a cultural layer about $1 \mathrm{~m}$ thick containing three distinct parts. The finds were dominated by cut wood, animal bones and pottery, but also leather, a piece of textile and some artefacts, among them a stone cannon ball (Appendix 1).

It was noted that the large pieces of wood and animal bones in layers 2 and 4 of the cultural deposit were not lying horizontal, which would have been the case if a small amount of waste had accumulated on the seafloor over a long period of time. Nor did the organic material have any signs of decomposition caused by bacterial- or erosion-related activity which would also have been the case if the material had been exposed on the seafloor. This suggests that the organic material has been sealed in an anaerobic environment, because of a continuous and massive deposition within a short time. Eight samples for radiocarbon dating were collected from secure contexts in the profile of test pit 1 (Table 1).

There is a good match between the dates, and since all samples, except two, come from short-lived animals, they are probably precise. There may be a slight chronological distinction between layer 2 and 4: layer 4 is perhaps somewhat older than layer 2 . Nonetheless, the dates indicate that the cultural layer here began to accumulate during the fourteenth century and that it ceased in the middle of the fifteenth century. It is possible that the end of activity is a little later since the samples were taken in the second layer, and not in the first and upper layer of sand and stones. The reason for this is that the upper layer is disturbed by living shells and erosion, which makes a vertical or horizontal context uncertain. Here the nondegradable objects, such as ceramics and bones are preserved, while the organic material has disappeared. It is 
Table 2. Date of buried soil horizon adjoining the stone building on Fårøy.

\begin{tabular}{|l|l|l|l|l|}
\hline Lab. ID. & Sample ID & Material & $\begin{array}{c}\text { 14C age } \\
\text { uncal. BP }\end{array}$ & \multicolumn{1}{|c|}{ Cal AD } \\
\hline UBA 19721 & C303 top & Sediment & $489 \pm 25$ BP & $\begin{array}{l}\text { 1 sigma 1420-1438 } \\
\text { 2 sigma 1410-1445 }\end{array}$ \\
\hline UBA 19722 & C303 top & Sediment & $256 \pm 41$ BP & $\begin{array}{l}\text { 1 sigma 1524-1558 } \\
\text { 2 sigma 1494-1601 }\end{array}$ \\
\hline UBA 19723 & C303 bottom & Sediment & $512 \pm 32$ BP & $\begin{array}{l}\text { 1 sigma 1409-1435 } \\
\text { 2 sigma 1326-1343, 1394-1445 }\end{array}$ \\
\hline UBA 19724 & C406 top & Sediment & $409 \pm 35$ BP & $\begin{array}{l}\text { 1 sigma 1439-1492 } \\
\text { 2 sigma 1430-1522 }\end{array}$ \\
\hline UBA 19725 & C406 top & Sediment & $260 \pm 21$ BP & $\begin{array}{l}\text { 1 sigma 1641-1663 } \\
2 \text { sigma 1527-1554, 1633-1666, 1784-1796 }\end{array}$ \\
\hline UBA 19726 & C406 bottom & Sediment & $115 \pm 36$ BP & $\begin{array}{l}\text { 1 sigma 1688-1713 } \\
\text { 2 sigma 1678-1765 }\end{array}$ \\
\hline
\end{tabular}

probably remains from this disturbed layer that is visible on the seabed in the harbour.

North-east of the sound is Gloppe bay leading to the north. To the east of Gloppe bay is the island called Bukkøy and to the west Gloppeneset leading to the church (Fig. 3). A stray find of a Siegburg stoneware jug from the fifteenth century was discovered in the southern end of the bay, close to the sound, together with another possible piece of medieval pottery. Flint ballast lies on the seabed close to the shore in Gloppe bay. Some less certain observations of ballast were made close to the entrance of the bay further north. In several places in the bay bones and cut wood could be observed. There are some jetties of unknown date along the shore, but they may be connected with the small trading village called Gloppe, which existed from the first half of the eighteenth century until the second half of the nineteenth century. ${ }^{15} \mathrm{~A}$ few small fragments of possible medieval pottery were found further north, together with fragments of a medieval griddle. These finds come from the area of a probable boathouse of likely medieval origin and from here roads lead to the narrow sound. There are a number of houses in this area, the majority probably post-medieval, but they are not dated, and some of them could be older.

On the north-east of the island of Fårøy is a significant area with three or four mooring cairns and a ruined stone building (Fig. 3). The heaps of stone interpreted as mooring cairns are built of large stones piled together and measuring about $3 \mathrm{~m}$ in diameter. The shore between the piles is cleared of larger stones out to a depth of water of 0.3 to $0.5 \mathrm{~m}$. This argues that the cleared areas were not landing places, because the stones further out would obstruct even smaller boats from landing on the shore. They are probably not from clearance either, since the stones obviously are collected on the shore and not in the meadow behind. Besides, there were no smaller stones in between, as is usual in clearance cairns. Anchored ships could fasten a rope around the piles which were probably used for mooring. Such mooring cairns were called in Old Norse ábord. This type of stone cairns may in some cases have supported a flagstone or a boulder, or a wooden pole. The latter alternative is most likely on Fårøy. The mooring cairns at Avaldsnes are the only examples known in Rogaland, except for one recently found on the island of Kvitsøy further south. This, like Avaldsnes, was also a good harbour close to an important viking and medieval site with a stone church mentioned several times in the saga literature. Underwater survey revealed another pile of stones on the seabed about $19 \mathrm{~m}$ from the shore on Fårøy. Here, three wooden poles and other pieces of wood were found during the surveys in the 1970s and 1980s. This was most likely a caisson filled with stones forming the foundations of a jetty.

We had hoped that a new test trench, test pit 2, close to the jetty and the mooring cairns would reveal if archaeological material here indicated reloading of cargo. Such material might be lost commodities or ballast, or rubbish dumped in the sea from the jetty connected to activities in the ruined stone building, but no traces of cultural layers or any archaeological material appeared. It is apparent

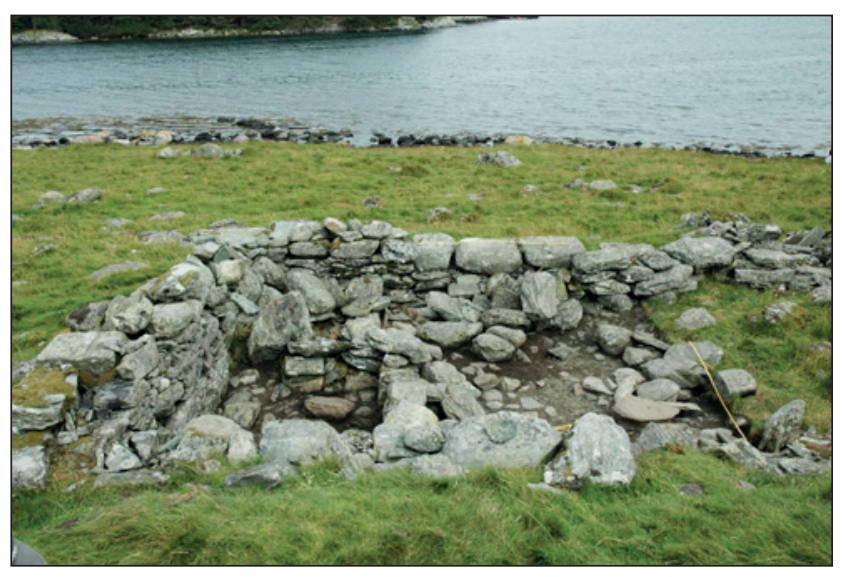

Fig. 4. Remains of the stone building on Fårøy during excavation, possibly dating to the fifteenth century (photo: Mark Gardiner). 
that rubbish was not thrown into the sea from the jetty, nor was ballast thrown overboard from ships moored to it. If it was a place for trans-shipment of goods, it left no material on the seabed. Another test pit, no. 3, was dug $10 \mathrm{~m}$ further out in the bay and here fifty-one animal bones and nineteen pieces of cut wood from approximately one square metre was found, together with one fragment of a stoneware jug. So, in this area the culture layer started approximately $40 \mathrm{~m}$ from land. This is consistent with the observation during the first investigations that pottery often could be found c. $40 \mathrm{~m}$ from land.

Natascha Mehler, Mark Gardiner and Endre Elvestad examined the ruined stone building. ${ }^{16}$ It is situated $30 \mathrm{~m}$ from the present shore where the mooring cairns and the start of the jetty are located. The building measured 8.7 by $4.9 \mathrm{~m}$ internally. The walls were built in a box wall construction, thick and insulated, and the building was partly set into the ground. The entrance in the south-western part was extended by a porch with one internal door facing east and one external door facing south. The doorways were rather narrow, about $0.9 \mathrm{~m}$ wide, and the porch was quite small. Repairs to the east wall suggest that the building had been in use for some time. Later during its lifetime, a stone flag floor was laid down. Against the west wall there may have been a bench, cupboard or other fixture. The width of the walls suggests that it was a more substantial structure than a single-storeyed building. The inference is that the thickness of the walls was determined by the need to support a further storey above the existing cellar. The building would thus have comprised a paved, but poorly lit cellar with entrance protected against northern winds and an upper wooden floor, probably entered from the west (uphill) side.

The building on Fårøy belongs to the Nordic tradition with a cellar set partially below ground level on a sloping hillside, but a significant difference between local vernacular buildings and the one on Fårøy is the latter's entrance which has no obvious parallel. Such an elaborate entrance would hardly be required for stock. The character of the porch also precludes the possibility that the building was used for the storage of bulky items, which could not readily have been brought in and out through such a tight turn with narrow doors (Fig. 4). The excavation revealed nothing to indicate the function of the building. There were no cultural layers and no significant finds. The absence of any traces of a fireplace suggest that this was not a dwelling, at least in the colder seasons. Yet there are insulated walls and a porch to prevent the cold coming in. Radiocarbon dates of the buried turf layer from the construction period indicates that the

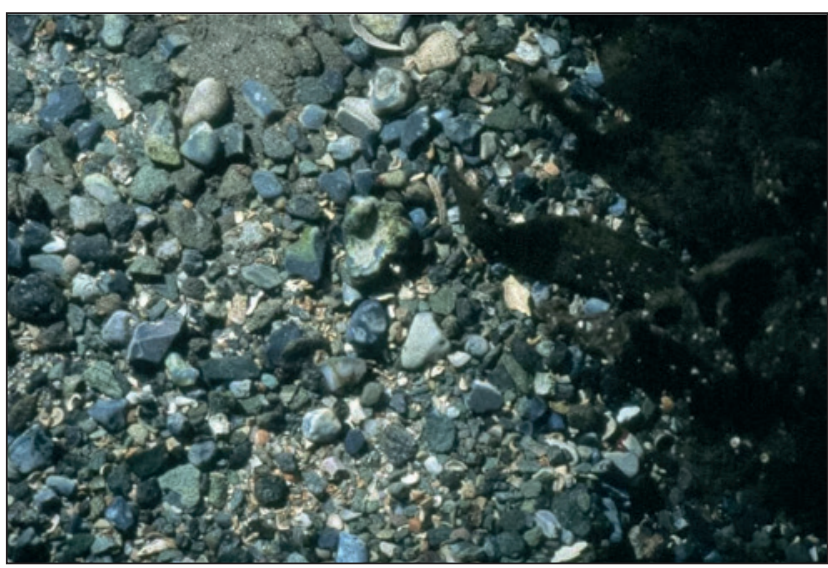

Fig. 5. Flint ballast found in the outer harbour (photo: Endre Elvestad).

house was built in the fifteenth century. ${ }^{17}$ This seems to mean that it was used during the most intense period of the deposition of the cultural layer in the bay beyond it (Table 2).

Two trenches were dug between the building and the jetty to search for a pathway or culture layers, but nothing was found. It has already been mentioned that the cultural layer started about $40 \mathrm{~m}$ out in the bay at a depth of $4.5 \mathrm{~m}$. The lack of finds on land is remarkable compared to the massive number in the sea. There were no post-medieval finds in the stone building either, material that is usually easy to see. It should also be added that no written records indicate any activity on Fårøy other than animal grazing and occasionally ships at anchor. ${ }^{18}$ Microfossil content from the fifteenth-century buried turf layer provided information about the local environment and land-management regime. ${ }^{19}$ The results indicated mainly open areas of heath or moorland used for grazing with small amounts of cultivated land. The thermally mature material suggested fire and the burning of wood. Spherules also indicate fire - these are the dark brown types which are generated by activities such as metal-melting, firing pottery and other craft operations involving strong heating of materials. ${ }^{20}$

Altogether the evidence gives the impression of a building with no apparent function. It is neither part of a settlement on Fårøy, nor an area for unloading and storing of goods, nor a workshop, though craftwork needing strong heat could have taken place nearby. From the site there would have been good sightlines to Karmsund and ships passing, and the building would have dominated the harbour at Avaldsnes. The mooring cairns and jetty on Fårøy are probably contemporary with the stone building. The lack of finds on land indicates careful management of rubbish disposal. Marianne Nitter from the Museum of Archaeology, University of Stavanger, 
Table 3. Date of bones from test pit 4 .

\begin{tabular}{|c|c|c|c|c|}
\hline Lab. ID. & Context & Material & $\begin{array}{c}14 C \text { age } \\
\text { uncal. BP }\end{array}$ & Cal AD, 20 \\
\hline Beta-337025 & T2A & Animal bone & $770 \pm 30$ BP & $1220-1280$ \\
\hline Beta-337026 & T2B & Animal bone & $920 \pm 30$ BP & $\begin{array}{r}1030-1190, \\
1200-1210\end{array}$ \\
\hline Beta-337027 & T3A & Animal bone & $840 \pm 30$ BP & $1160-1260$ \\
\hline Beta-337028 & T3B & Animal bone & $800 \pm 30$ BP & $\begin{array}{r}1190-1200, \\
1210-1270\end{array}$ \\
\hline
\end{tabular}

analysed the anchorage outside the house using the fetch method whereby the height of the waves where calculated. Her conclusion was that this was the best place to anchor ships in the bay, something also suggested by the mooring cairns. ${ }^{21}$

The location of the building on Fårøy close to a harbour used by international merchants in the fifteenth century forces us to consider whether it could have had some specialized function for which there would have been few obvious comparators, at least in a rural context. A will from 1425 indicates that merchants from Lübeck were involved in building activity at Notau, but it is impossible to know which building(s) that was. A stone building, which was not a church, a monastery or an aristocratic hall, would be a strange sight in this landscape where all the farmhouses were made of wood. The mooring arrangement and jetty close to the building were large enough for big ships. Since the building was not for storing, nor for living or sheltering cattle, and there were no finds either inside or outside, it is tempting to propose that it might have had some kind of administrative function. ${ }^{22}$

South-west on the island of Bukkøy we discovered a pile of stones similar to that located near the shore on Fårøy on the other side of the bay (Fig. 3). This had also probably served as the foundation of a jetty. There is ballast dumped on land in that area. Ballast was also found close to a small cliff formation probably used for loading ships as well as on the seabed close to the pile of stones. The ballast in the sea is made up of blue flint and covers a large area where it had been dumped on shallow water with a depth of no more than $1 \mathrm{~m}$ (Fig. 5). This makes it hard to believe that the flint was thrown overboard from a large trading ship. A possible explanation is that the purpose was to surface the bottom to make it easier to land with small boats. Here, as everywhere else in this harbour, the bottom layers are extremely muddy, and therefore difficult to walk on. Such a surfacing of the bottom is known from other Iron Age and medieval ports in Norway and on the Continent. An important observation was that in a few specific areas at Bukkøy, animal bones and cut wood were found very close to the shore. This is in the same areas which also have ballast on land. It might be an indication that there was activity on Bukkøy producing rubbish. Storehouses could also have been located here, but recently planted spruce trees have grown into a dense forest and make archaeological survey on Bukkøy difficult.

Test pit 4 was dug close to the jetty in an area where no finds were visible on the seabed. The pit was about $1 \mathrm{~m}$ square and the finds consisted of two animal bones in a $0.2 \mathrm{~m}$ deep organic layer. Samples were collected for radiocarbon dating (Table 3 ). These provided older dates, mainly from the thirteenth century, and possibly as early as c. 1190. The last test pit, no. 5, was dug $10 \mathrm{~m}$ further out and finds here consisted of chopped wood.

On the north of Bukkøy there are some well marked tracks indicating traffic across the island. The tracks are so deep that they could possibly have been used to drag something quite heavy. To the north of the island is the bay called Nora Nottå (North Nottå), one of the placenames which probably refer to Notau. Ballast has been observed in the sea. On the northern part of Bukkøy, close to the place called Nora Nottå, is an area where fine sand, not of local origin, has been deposited.

Systematic surveys in the outer bay revealed stray finds of pottery and large amounts of animal bones visible on the seabed together with ballast heaps. An important observation was that the finds ceased at a clear line marked by a small skerry (Fig. 3). Beyond this point there were deposits of ballast, consisting mainly of broken bricks, some flint and limestone. In the outer bay items of trade were found, among which was an unfinished whetstone of Eidsborg schist from Telemark, east Norway. Scattered finds of objects clearly intended for trade could indicate that they were lost while being moved from one ship to another while the vessels lay at anchor. The ballast heaps, which are of material clearly not of Norwegian origin, may indicate that cargo was loaded from Norwegian ships on to foreign ones.

It is possible that the finds presented so far represent the central part of a harbour, but a much wider area could have been used in different ways. A stray find of medieval pottery was made in the sea at Høyevarde, about $2.5 \mathrm{~km}$ south of Avaldsnes. Høyevarde is called Warder or Groot Warder on the Dutch sea maps (Fig. 2), and was a muchused harbour in the Early Modern period. A small island south of Høyevarde, named Perdeholm in Low German (Norw. Hestholmen), is marked on some of the oldest maps. On the island of Stutøy, between Høyevarde and Avaldsnes, there is an inlet known as Søra Nottå (South Nottå). The inlet with a good sandy shore is situated on 
the eastern part of the island facing Karmsund. A building complex consisting of one or two ruined stone houses on the western part of Stutøy shows some similarities to the probable fifteenth-century stone house on Fårøy. A small underwater survey was carried outside the buildings, but no finds were discovered there.

\section{Conclusions from the maritime archaeological investigations}

The test pits and the extensive and systematic surveying of the seafloor at Avaldsnes revealed medieval finds almost everywhere in the harbour, not only in the large bay, but also in the surrounding inlets. The cultural layer, together with observations of stray finds visible on the seabed, cover a conservative estimate an area of approximately $7000 \mathrm{~m}^{2}$. Further survey is likely to increase the area of finds. In particular, the northern bays look promising. Based on information from both the investigations in the 1970s and 1980s and from the new trenches, it seems that the natural seabed in the main harbour area is covered by a cultural layer with a depth from 0.2 to $0.9 \mathrm{~m}$. It is assumed that this cultural layer originally could have been 0.2 to $0.4 \mathrm{~m}$ thicker, because the top layer of mud and other organic material has been washed away or decayed. The only remains from this top layer are objects which can resist rapid decomposition, such as pottery and large animal bones. These are the finds now visible on the seabed. The culture layer appears to be relatively homogenous and dominated mainly by animal bones, cut wood and pottery. The organic material is remarkably well preserved.

The surveys and the test pits have revealed large quantities of material that points towards intense activity in the harbour. The extent and composition resemble the cultural layers found in medieval towns. It seems that in a period of approximately a hundred years, roughly from sometime in the fourteenth until the middle of the fifteenth century, a cultural layer with a maximum thickness up to approximately 1.2 to $1.4 \mathrm{~m}$ accumulated. The thirteenth-century dates from a thinner cultural layer southwest of Bukkøy also indicate the use of the harbour from the time of the royal manor in the High Middle Ages. The end of the most intense period of activity is likely to be in the middle of the fifteenth century, but there might be a continuing use until the early sixteenth century when the activity in the harbour seems to cease. The cultural layers in the harbour area at Avaldsnes consist of medieval rubbish deposits, but where did they originate? Was it the result of activity on board ships and dumped from them, or did it come from a settlement ashore? Could there have

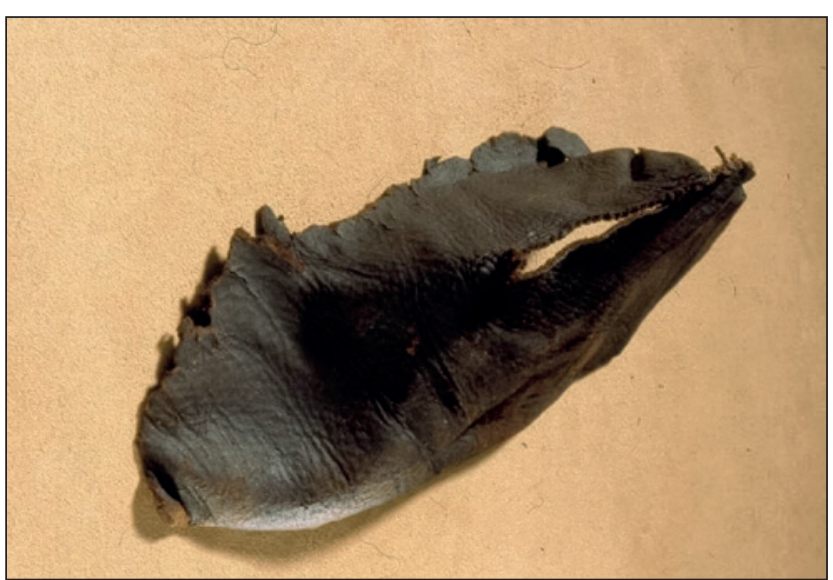

Fig. 6. Leather shoe found during the first investigations c. 1980 (photo: Terje Tveit. Museum of Archaeology, University of Stavanger).

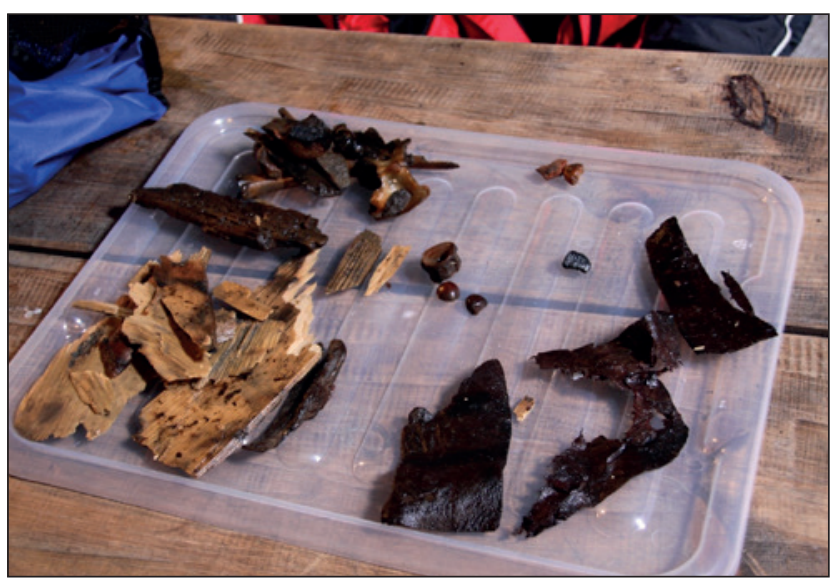

Fig. 7. Material from test pit 1 with cut wood and leather (photo: Cathrine Glette, Nordvegen History Centre, Avaldsnes). See also Appendix 1.

been a significant area with buildings used for storage, trade and craft not yet located? Most of the waste, except the ballast which was dumped from anchored ships, might have come from both vessels and settlements. However, bones were observed so far from the shore as to make it unlikely to have been deposited from land. The homogeneity of the layers with cut wood together with the bones also indicate that most of the rubbish was probably produced in a settlement on land. The concentration of rubbish in some specific areas was observed very close to land but not on the shore. This points to the rubbish being neither deposited from land, nor from ships anchored in the harbour. Our hypothesis is that the rubbish was loaded on barges and dumped in deeper areas where it would not reduce the depth for sailing vessels. This was a well-known problem in many medieval ports. An organized handling of rubbish carried or transported on barges and thrown into the sea indicates a settlement 
of a certain size, and that inhabitants had clear ideas of how to handle waste. The largest proportion of rubbish was waste from slaughtering. We consider it unlikely that animals were slaughtered on board ships in such large quantities. It is more likely large-scale butchering would be done on land, close to a good source of water. Many of the broken cooking pots, which were a frequent find, had soot underneath. They must have been used to prepare food in a settlement. Fragments from cooking pots on land could indicate where the settlement was located. The same can be said about the jetties. They were probably built to handle heavy or voluminous goods being brought to and from ships.

The questions related to activity on land must for the time being remain mostly unanswered. The stone ruin on Fårøy indicates that buildings were erected during the most intense phase in the harbour. Bukkøy also stands out as a plausible place for some sort of activity, loading or storage. Very little is known about the rather large area with houses and boathouses in the inner part of the harbour.

\section{The finds from the harbour}

Animal bones formed a large proportion of the archaeological objects from the test pits and visible on the seabed. Analysis made by Sean Dexter Denham show that they come mainly from cattle, sheep and pigs in that order. The material also included bones of a domestic fowl, a rat and fish. The number of bones is not statistical significant, so the preliminary conclusions may be altered when more samples are collected. The type of bones and working marks indicate an industrial slaughtering and processing of hides, skin and meat. ${ }^{23}$ From this perspective, it is interesting that most of the leather fragments found in test pit 1 were off-cuts (Appendix 1). Except for one piece that had pinholes, there are no other traces of working the leather. The pieces of leather suits well with Denham's preliminary conclusion - a possible existence of a leather industry or workshops at Avaldsnes. The cut leather with holes and the shoes found during the excavations in the 1970s and 1980s might be leftovers from shoe-making (Figs 6 and 7).

Another large body of material fragments of wood, including cut branches and woodchips, is probably cut by axe or other edged tool. Although we have not done an analysis to determine the tree species, there seems to be much oak present. This is interesting because oak did not grow in this district in the medieval period, nor was oak used in timbered houses. It is apparent that oak had been transported to the harbour at Avaldsnes from woods located further inland in the fjords. The oak woodchips could be leftovers from shipyards, either from building ships or repairing them. Remains of cut oak could also come from processed wood intended for trade. In the sixteenth and seventeenth century much timber was exported from the region, especially to the Netherlands and Scotland, but at that time the trade took place further inland in the fjords and closer to the woods. ${ }^{24} \mathrm{We}$ have one find of a fifteenth-century Siegburg jug from the most central of these export harbours, Nedstrand, and customs records from eastern English ports show timber imports from south-west Norway at the beginning of the fourteenth century. Among the ships in this trade was Avaldsnes-bussen (buss was a medieval clinkerbuilt trading ship) that brought processed timber (bord and bjelker) to King's Lynn, but it is possible the ship left from Bergen. ${ }^{25}$ Local trade in processed timber (bordved) took place at Avaldsnes at least on two occasions in 1554. So, it is possible that at this time Avaldsnes was a staple site, selling timber that originally came from the fjords in Ryfylke, further to the east. ${ }^{26}$ We may speculate that sometime in the sixteenth century a change of regulation may have taken place. Before that time the timber trade with foreigners may have had to take place at Avaldsnes, a libero portu Regio, while later foreign ships were allowed to sail directly into the fjords.

Ballast was found at all the anchorages at Avaldsnes, sometimes close to the shore, sometimes further out in the bays, and also at a few places ashore (Fig. 3). Ballast is visible on the seabed as areas of flint and bricks. Flint does not occur as a natural bedrock in Norway. Single stones could have been transported by ice drifting from Denmark or England during the Ice Age but greater concentrations of flint are almost certainly ballast dumped in the sea from an anchored ship. A common feature is that the stones have the same characteristic colour, size and shape caused by erosion. Large deposits of flint occur mainly in the towns of eastern England and in Rotterdam (Fig. 5).

The bricks are usually of similar colour and fabric, the same size, and broken or crushed. Whole bricks rarely occurred. The majority are probably medieval. Since the Norwegian production of bricks was limited in the Middle Ages, it is likely that they came from towns abroad where broken bricks were more easily obtainable than natural stone. The light grey sand in layer 3 from test pit 1 could be ballast too (Appendix 1). Light grey sand is not common in the sediments in the Avaldsnes area which is dominated by darker grey/green volcanic bedrock. Since layer 3 was quite distinct from layers 2 and 4 and there were no other archaeological objects 


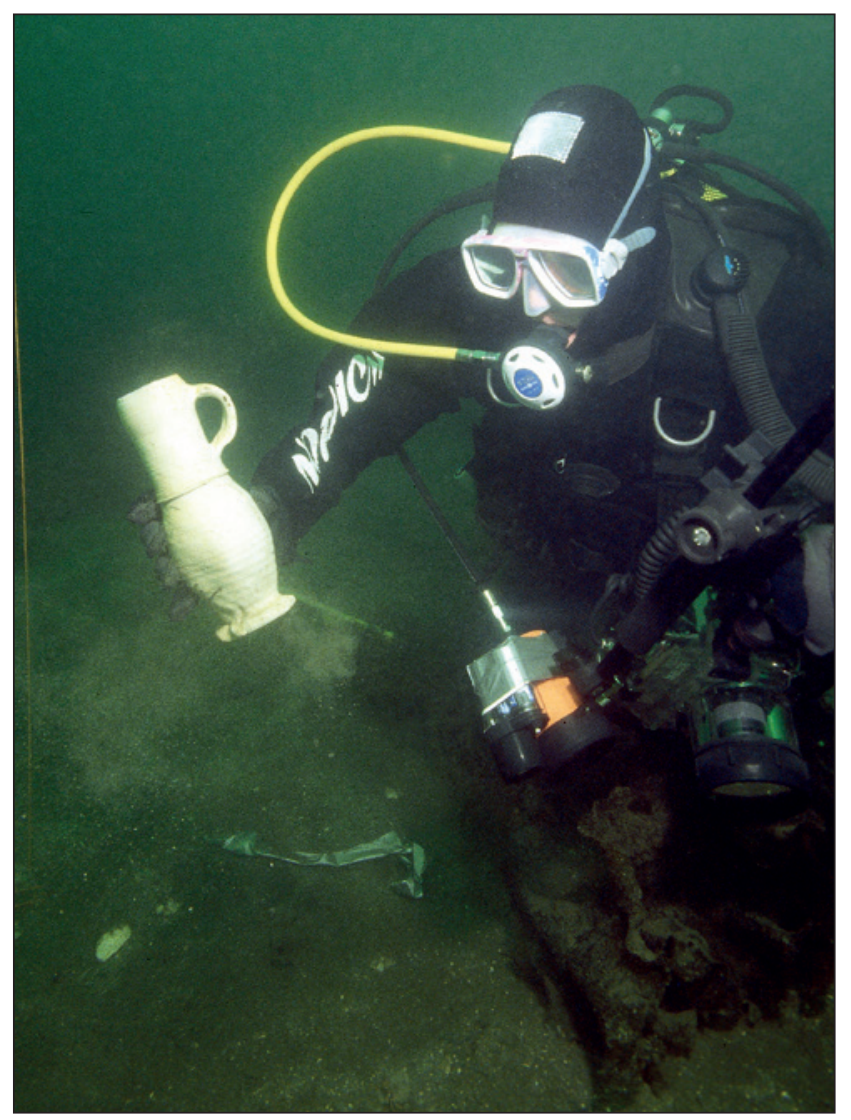

Fig. 8. Siegburg pottery found in the outer harbour (photo: Rudolf Svensen).

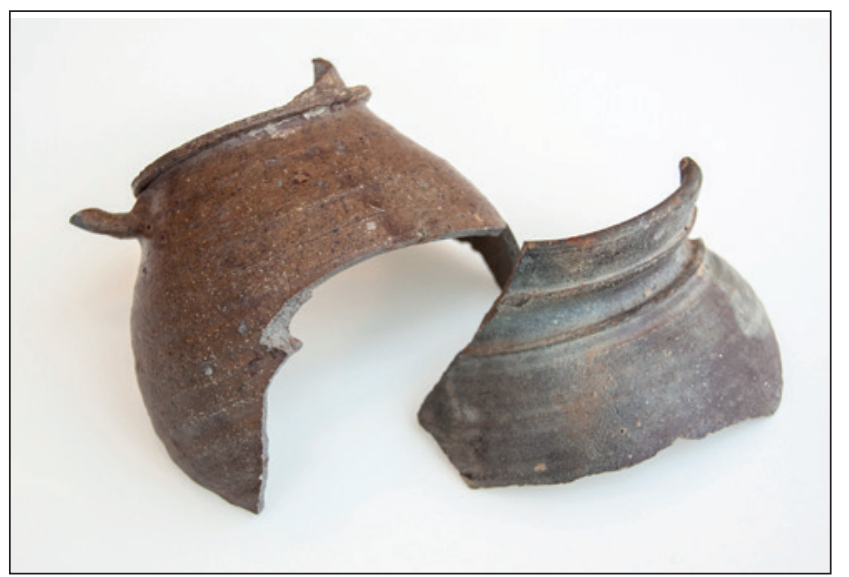

Fig. 9. Stoneware from the southern part of Lower Saxony, Germany, found at Avaldsnes (photo: Cathrine Glette, Nordvegen History Centre, Avaldsnes).

in it, it is most likely a single deposit dumped from an anchored ship. Limestone was also found in a few of the ballast heaps and large amounts of coal are likely to be ballast too. Coal was probably not imported to Norway in the medieval period, due to almost endless resources for production of charcoal in the woods. Not far from test pit 1 there is a distinct area where the seabed is covered with coal. It is highly probable that the coal there is ballast.
We have also found coal in two other medieval harbours in Rogaland, and at both places the coal came from ballast heaps. The coal might be an indication of contact with ports in eastern England, probably the northern part of the coast. Ballast needs to be cheap or free. There are not many places around the North Sea where coal is as easily available as Newcastle and northwards, especially Northumberland. Here sea coal is washed up on the beaches from terrestrial or underwater deposits.

The recorded ballast heaps at Avaldsnes are probably only a small part of the total. Experience from similar investigations indicates that beneath the surface of the seafloor the heaps are much larger, and that the flint and bricks might be a small part of the ballast. Very often the ballast also contains sand, gravel and stones which can be difficult to distinguish from the surroundings. Ballast is used to weigh down ships with little or light cargo to make them stable. The ballast was loaded in the exit ports and dumped in the ports of call if the ships were to load heavy cargo. The ballast deposited at Avaldsnes shows that something heavy was loaded into ships in the harbour area, but it is difficult to quantify the extent of the ballast and the amount of cargo which replaced it. The ballast consisting of flint and probably the bricks are not of Norwegian origin and therefore a very good indication of international trade. The ships coming from the Baltic were in general heavily loaded and did not need ballast. ${ }^{27}$ Two English ships arriving at Notau in 1454 are said to have carried textiles (linen) and wine. ${ }^{28}$ Ships with such cargo would have needed much more ballast than a vessel carrying grain and beer. This is consistent with the general impression that cloth, wine and other fine commodities came from England, the Netherlands and the North Sea part of Germany. It is likely that the ballast indicates such contact, but it is uncertain if it reflects Hanseatic trading routes in the fifteenth century or Norwegian or Western European trading routes known from the earlier part of the fourteenth century.

The total of fifty-five pieces of pottery found in the harbour area at Avaldsnes have been examined by Volker Demuth, and many are big, nearly intact or complete vessels. ${ }^{29}$ The majority of finds were random pieces lying visible on the seabed without context, except for their location. It is reasonable to assume that these finds are a small part of the total, and that there is much more further down.

Some of the collected ceramic objects are from the thirteenth and fourteenth centuries, but the typical pottery were types from the fifteenth century and were still in use in the first half of the sixteenth century. The principal artefact was stoneware drinking jugs from Siegburg 
Fig. 10. Bone handle and stamp seal found at Avaldsnes (photo: Cathrine Glette, Nordvegen History Centre, Avaldsnes).
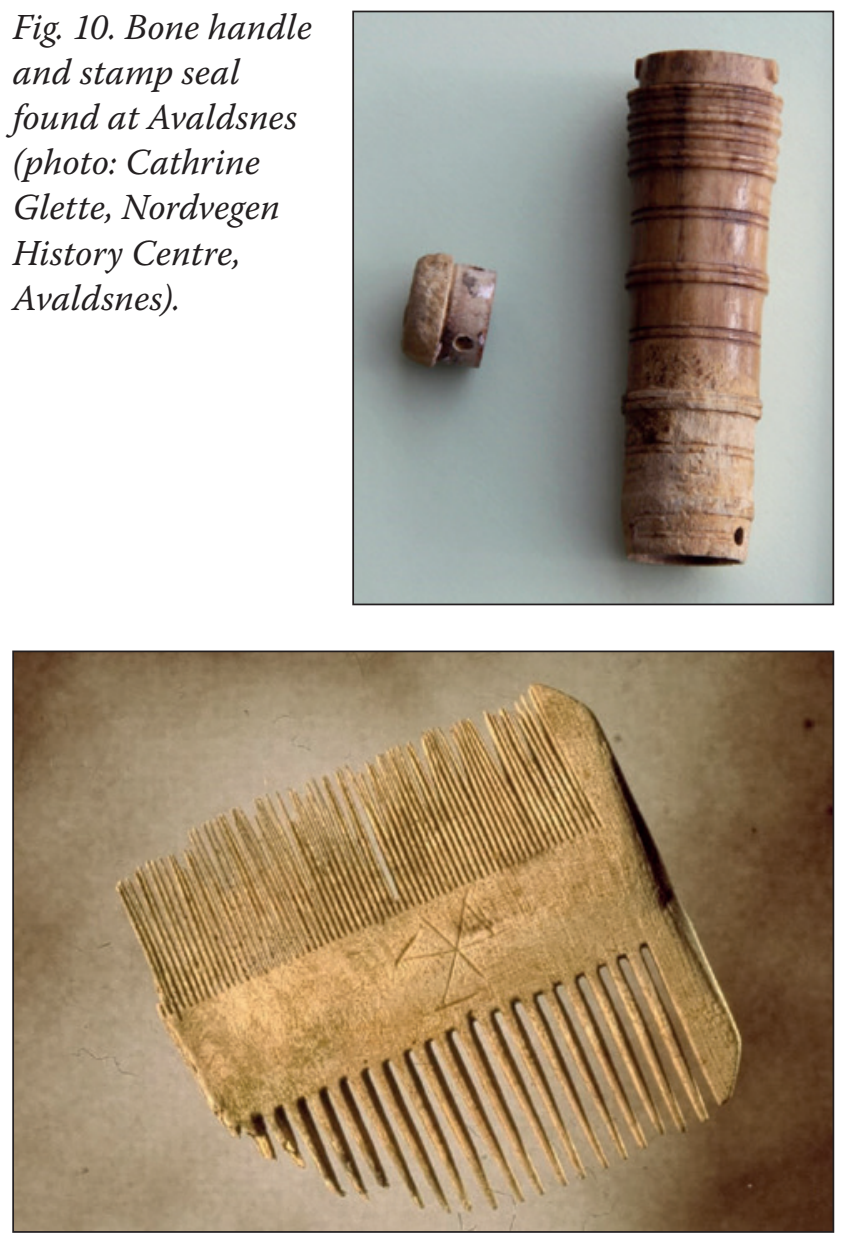

Fig. 11. Bone comb with markings found c. 1980 (photo: Terje Tveit. Museum of Archaeology, University of Stavanger).

or other production sites in the Rhine area, dating to the fourteenth and fifteenth century, many being remarkably intact. Almost all of the smaller fragments of pottery stem from red glazed earthenware, which was a quite common artefact in the harbour. These were mainly cooking pots from the fourteenth and the fifteenth century. Demuth suggested that the provenance of the majority of the redware probably was the Netherlands, while a smaller amount came from Denmark. He has drawn our attention towards the significant amount of pottery found at Avaldsnes originating in northern Germany and the Netherlands. Some of the stoneware from the Rhine area might have been reloaded in North Sea towns. The towns of Deventer, Kampen and Zwolle are mentioned in written sources of 1476 and 1477 in connection with Notau. A ship from Deventer is also mentioned in 1405, and contact with Deventer is reflected in 1519 when farmers on Karmøy paid their taxes partly with Deventer cloth (Deventerklede) (Figs 8 and 9). ${ }^{30}$

The ceramic finds from the fifteenth century are so dominant that they appear to be a general tendency. ${ }^{31}$
There are a few objects dating from $c$. 1600, mainly from the Netherlands, such as two from the Weser area produced c. 1570-1630. These finds could well be from the last international use of the harbour. Demuth points out that the Weser pottery could have come from Bremen, a Hanseatic town which historically had close connections to Norway. ${ }^{32}$

All in all, the pottery seems to reflect an intense activity in the harbour area at Avaldsnes in the late Middle Ages, particularly during the fifteenth century. ${ }^{33}$ The distribution of the jugs on the seabed indicates they were lost in the sea while loading or reloading between ships were taking place. It is not likely that new jugs were discarded, although the broken ones might have been thrown overboard. The fragmented and used pottery in general could stem from some sort of Hanseatic settlements close to the harbour area. The Siegburg jugs were probably not intended for sale but rather to be used by the merchants themselves. The locals probably did not buy them, and they are usually found in the Hanseatic settlements. ${ }^{34}$

Demuth pointed out the importance of few or the absence of pottery fragments of English origin and also the lack of pottery older than 1300. Such finds are common on the greater medieval sites elsewhere. English pottery, for instance, is predominant in the medieval towns of Bergen and Stavanger in the thirteenth and early fourteenth century. So, the lack of English pottery suggests that the activity in the harbour area at Avaldsnes started to increase after this period, though as Demuth argued, the finds come from the top layer and the English material might be present, but further down. ${ }^{35}$

One of the fish bones found in the harbour at Avaldsnes had a $\delta C^{13}$ ratio that suggests that the fish were from fresh water. One bone is, of course, not sufficient evidence, but there were important fresh water fisheries of salmon in Rogaland in the Middle Ages. The barrel staves from the outer harbour could reflect trade in salted fish, but other items were also transported in barrels. Further finds connected to fishing were a net sinker and perhaps some wooden needles appearing in the cultural layer. The function of the latter items is unclear, but they might have been used to hold fish open when drying it.

About two hundred objects have been collected from the harbour area including those from the old investigations and random finds. As already pointed out, this is but a small part of the total and most consists of finds from the eroded top layer visible on the seabed. Some of the objects are rare and even unique. A stamp made of bone or horn could possibly be a direct link to Hanseatic mercantile activities. That type of stamp is depicted on a painting by Hans Holbein the Younger dated 1532 showing a 


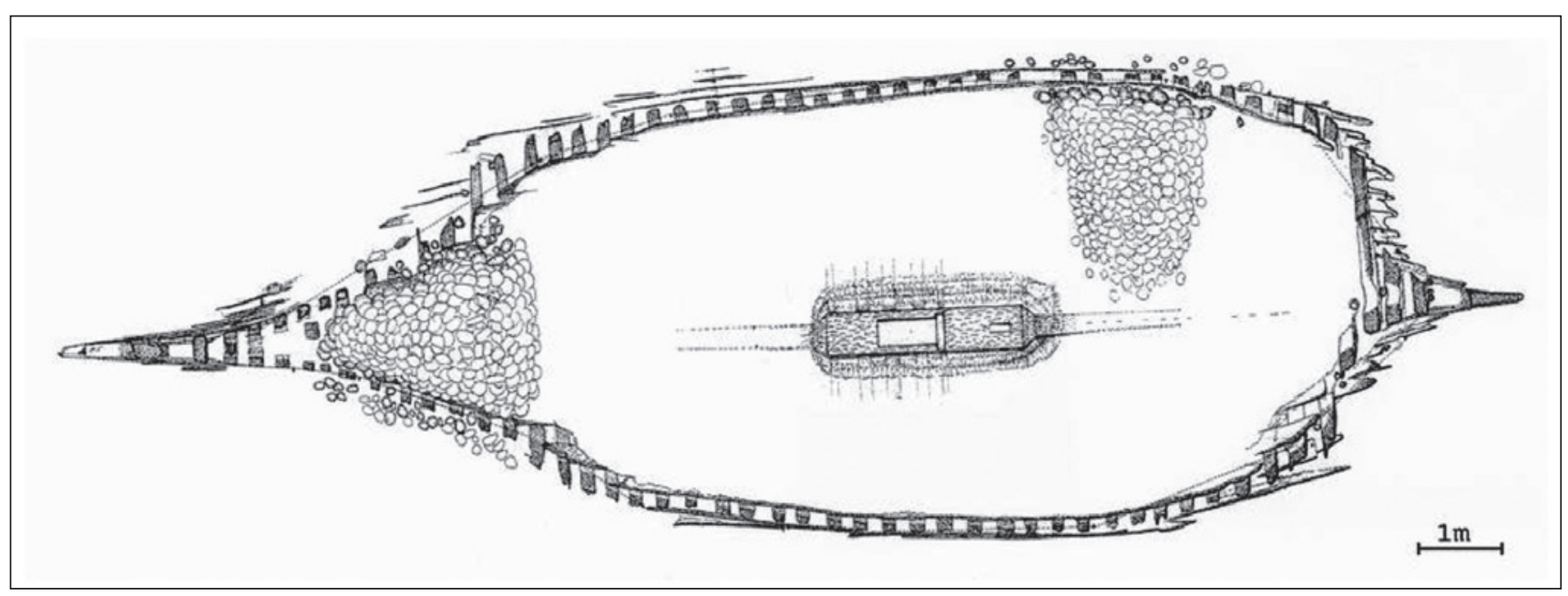

Fig. 12. The late medieval shipwreck in the harbour of Avaldsnes (illustration: Harry Alopaeus).

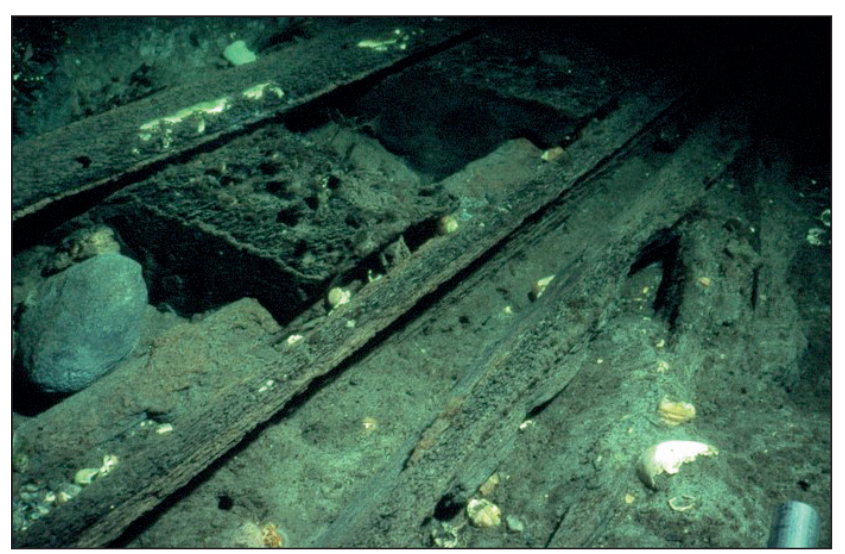

Fig. 13. The remains of the late medieval shipwreck in situ at Avaldsnes (photo: Torstein Ormøy).

merchant from Danzig staying in London. Here a stamp occurs together with a metal seal matrix. It was used to sign documents. The stamp has a mark similar to the Hanseatic house-marks, and resembles the house mark used in a Danzig merchant house in the fifteenth century. A possible house mark is also found on a comb (Figs 10 and 11). Inscriptions on a steatite door jamb and on a wooden door from the church at Avaldsnes may also have been made by Hanseatic merchants. Another rare object is a fragment of a pilgrim's horn. It was probably manufactured in the village of Langerwehe close to Aachen in the fifteenth century. ${ }^{36}$ Among the finds is also a mortar made of Rhine basalt. Some carnelian was found, which in Europe most commonly originates in Germany. A stone cannon ball appeared in layer 2 in test pit 1 close to the narrow sound (Appendix 1). The location in the probably undisturbed cultural layer makes a fourteenth- or fifteenth-century date probable. An iron cannon ball from an unknown place on Bukkøy had the same dimensions. The stone cannon ball was most likely lost from a ship carrying cannons, but trade in weapons is known. A conflict between two English ships and a Danish ship carrying 70 cannons is said to have taken place in Skudeneshavn at the southern entrance of Karmsund in $1478 .^{37}$

Some of the finds are indicators of trade. In the middle of the outer harbour area an unfinished whetstone and barrel staves, probably lost while loading on board another ship, were found. There are also some unused cooking pots, possibly from North Sea towns, which could be traded items. Whetstones from Eidsborg in Telemark were traded by the Hanse, and several such whetstones have been found, for instance, in Gdansk (Danzig). But such trade in whetstones had long traditions going back to the Viking Age and cannot exclusively be tied to the Hanse. ${ }^{38}$ Two stoneware jugs, a piece of a barrel and the unfinished whetstone were found so far out in the bay that the ships could not have been moored on land. This is the obvious place for ships to lie only at anchor, with enough space to sway freely. Thus, these finds seem to indicate reloading from one ship to another, or to smaller boats, which might in itself reflect trade.

\section{The shipwreck}

The remains of a shipwreck lie in shallow water in the inner part of the harbour. A dendrochronological analysis indicates that the ship's timber was felled in the southern Baltic, most likely the Gdansk-Elblag area in Poland around $1395 .{ }^{39}$ A small trench dug in 2003 showed that the remains today are about $18 \mathrm{~m}$ in length, but the ship was originally about $22 \mathrm{~m}$ long, $6 \mathrm{~m}$ wide and $5 \mathrm{~m}$ high. ${ }^{40}$ The bottom section is remarkably well preserved, the fresh yellow colour of the oak still being visible under the mud. The ship is clinker-built with the planks overlapping each other, and has a deep, sharp keel that shows 
it is not a cog. The planks, frames and inner planking are of solid oak. Animal hair placed between the planks sealed the ship, while the areas where the planks were attached to the bow and the stern were caulked with moss (Dreponocladus vernicosus). The moss is further evidence that the ship was built in the estuary of the Vistula river. The keelson, which supported the mast, was made of a large piece of wood and held in place by five massive beams installed along the ribs. The ship had a wide, crooked bow and a narrow, straight stern. It was built in a combination of Scandinavian shipbuilding traditions and those used in the Baltic Sea area. The size of the vessel and the construction indicates a solid cargo ship built for long-distance journeys. Small twigs were found in the central part inside the ship. They probably come from a covering in the hold to protect the cargo from humidity, or to protect the ship against a heavy load. It is most likely to have been a trading ship capable of carrying both heavy and fragile cargoes. There are some indications that the ship burned before it sank (Figs 12 and 13).

Fragments of different types of tiles were found inside the ship, among them a green-glazed floor tile. Tiles also appeared in the two stone cairns found one in each end of the vessel. A wooden pole, $0.2 \mathrm{~m}$ wide and made of oak, lay close to the ship.

The origin of the ship timber and the dating correlates well with the written sources indicating that Notau was visited by merchants from Danzig in the fifteenth century. ${ }^{41}$ One of these sources tells that a ship from this important Hanse town was wrecked in Notau in 1430. The cargo was salvaged. ${ }^{42}$ It is possible that this actually refers to the shipwreck found in the harbour at Avaldsnes, in that case it was about 35 years old when it sank, but this cannot be proved.

The closest parallel so far seems to be a ship found in the harbour of Gdansk, the so-called Copper ship (ship no. W5). ${ }^{43}$ It also appears to have some similarities to the Skjernøysund 3 wreck from Skjernøy, the Foldøyhamn wreck from Foldøy, the Hundvika wreck found in the Farsund fjord, the Bøle ship from the Skien fjord and the Skaftö wreck from Gåsöfjorden in west Sweden. It is suggested that these were large clinker vessels built from southern Baltic oak, possibly in the Gdansk-Elblag area which was an important centre for boat-building in the Late Middle Ages. ${ }^{44}$ The Avaldsnes ship and the Copper ship are similar in many aspects. They were originally of the same length and made of oak. The same building method had been applied: the hulls were made by using the overlap method and sealed with animal hair and moss. The shape is almost identical. Both ships were merchant vessels designed to sail long distances and carry large amounts of cargo. The Avaldsnes ship is involved in a discussion about a type of ship known in the written sources as a holk, a type linked to the southern Baltic, but which has proved to be very difficult to identify for certain in the archaeological material. ${ }^{45}$

\section{What was Notau?}

Avaldsnes' strategic position in Karmsund at the point where several long-distance and regional sea routes met, and where the Bergensled began, is undoubtedly the main factor behind the importance of the harbour here. Some of those sea routes appear to be direct. For example, the oldest written pilot in north Europe simply states that the course from Walcheren in the Netherlands to Skudenes, where Karmsund starts in the south, is northnorth-east. The good harbour facilities for pre-modern ships together with the need for a harbour for waiting contributed to make Avaldsnes a natural place to stop for most ships travelling along the fairway. Many ships reached the southern entrance to Karmsund in a very poor condition in the seventeenth and eighteenth centuries after dangerous and dramatic sea crossings. ${ }^{46}$ Although the written evidence is lacking, this was obviously the case also in the late Middle Ages. A harbour at Avaldsnes could thus have been vital to repair ships and provide new provisions before the voyage continued.

Karmsund offered seafarers protection from the natural elements - the strong winds and heavy seas - but just because of that it could also be a potential dangerous place to pass. Piracy was a major problem in the late Middle Ages. Valuable trading goods transported through the narrow Karmsund must have tempted freebooters and pirates. If the king granted the harbour at Avaldsnes the status of a libero portu Regio, this, at least in the beginning, could have included a guarantee for a peaceful and safe stay there. Seen from the Hanseatic point of view, a stronghold at Avaldsnes, controlling the traffic through Karmsund, a bottleneck on the route to and from Bergen, must have been of prime importance. A possibility is that the ruined stone building on Fårøy, with its remarkable lack of finds, could have had military functions guarding the activity in the harbour. The existence of a blockhouse is recorded in a fifteenth-century written source describing a waiting harbour in Agder, southern Norway. ${ }^{47}$ This was probably a site involved in the same maritime route from the Baltic as Avaldsnes.

A well-preserved harbour of international importance located at a significant royal manor outside of the medieval towns has never been investigated in Norway before. The relationship between the Norwegian king and the 
Hanse is, of course, of importance as concerns the history of Notau. Around 1250 political processes began that involved a change in Norwegian foreign policy. ${ }^{48}$ A motivation for this was probably the need to secure the import of grain. The trade expansion of the German merchants was obvious, especially from late in the reign of Håkon Håkonson (1219-1263), and around 1300 the Hanse achieved the right to trade from Bergen and southwards. At about the same time, the economic contacts with England and Denmark appear to have become less important. ${ }^{49}$ From about the mid-thirteenth century the Norwegian king started developing harbours to facilitate trade with German towns and those in the Baltic. The kings established what Knut Helle has called 'harbour stations' ${ }^{50}$ Avaldsnes is not mentioned in connection with this project, but there were significant royal investments from the 1250s onwards through the building of the big church dedicated to St. Olav which shows the increasing importance of the place for the king. By the early fourteenth century, we find here a clergy with administrative competence, a major assembly site and a place of political power. The harbour could have been organized in ways that made it different from the surrounding area, including special regulations and guaranties. The possibility that it was Notau which was called a libero portu Regio around 1440 could prove important to achieve a greater understanding of such a type of harbour.

It is thus relevant to speculate if the political changes from around 1250 onwards laid the foundation for the later Hanseatic presence in Karmsund. In the late Middle Ages, when the king no longer resided in Norway on a permanent basis, royal control of the activities in the harbour at Avaldsnes could gradually have diminished.

The middle of the fourteenth century seems to be a vital period in the history of towns and trading places in western Norway. The heyday of localities like Veøy in Romsdal, Borgund in Sunnmøre and Kaupanger in Sogn was from the twelfth century until around $1350 . .^{51}$ Afterwards, activity at these places decreased and they became partly abandoned. The harbour area at Avaldsnes, on the other hand, rose to prominence from around the middle of the fourteenth century onwards. The thick cultural layers on the seabed leaves no doubt that there was an intense activity here for roughly a hundred-year period. This phase appears to have started sometime in the fourteenth century, possibly in its second half, and led to the establishment of the place called Notau. Even though the remains of jetties, houses and mooring cairns are difficult to date, we find it likely that they reflect this process. The importance of Notau clearly was at its greatest during the fifteenth century and, in particular, between 1400 and 1450 . The expansion of facilities here must have represented an investment and organization that far exceeded the needs of an ordinary waiting harbour along the main sea route to Bergen. The accumulation of cultural layers was so intense that some of the organic material never became exposed to erosion. This resembles the accumulation of waste in medieval urban layers, for instance in Bergen.

The pottery from Avaldsnes show significant similarities with ceramic finds in Bergen, mostly consisting of the same types from the same periods. The major difference is the lack of English pottery at Avaldsnes which could indicate that the activity in the harbour here started a little later compared to Bergen..$^{52}$ Notau was clearly part of the same network and economic activity as Bergen with ties to Lübeck and Danzig. The proximity to Bergen, the strategic position in Karmsund, and the possible localisation of the fourth Kontor there for a short while, ${ }^{53}$ makes Notau a part of the central organization of the Hanse.

When we consider the archaeological material in light of the written sources, it seems that merchants from Lübeck had a central position in developing the harbour at Avaldsnes. They could have established the site called Notau at about the same time as they founded the Kontor in Bergen, that is around 1360. The will of 1425 referring to Notau without finding it necessary to state where it was situated, suggests that the place was well known to the merchants in Lübeck. Other written sources, together with the previously mentioned shipwreck, and perhaps also some house marks, show close connections to Danzig. Several documents and probably pottery indicate that also ships from German and Dutch North Sea towns used the harbour facilities at Notau. The ballast might have a west European origin, but is difficult to date.

The finds could give the impression that an urban culture and identity developed at Avaldsnes during the fifteenth century, influenced by the Hanseatic merchants. The Siegburg jugs were not trading goods for sale to the local population. David Gaimster has investigated the distribution of these jugs in northern Europe, and concludes that they are found mainly in areas with a population of Hanseatic merchants, especially in Scandinavia and the Baltic. ${ }^{54}$ Such jugs are strongly connected to the drinking of wine and beer, which was an important activity among the urban merchants. The drinking rituals constituted a symbolic expression of solidarity and fellowship, creating distance to the locals and unity within the group. ${ }^{55}$ Pirates created a threat to trade and, in addition, the kings and local nobility and merchants often opposed the Hanse operating outside its home ports. To keep the Hanseatic network together it was necessary to 
have a strong social organization, and one way of creating unity was through eating and drinking rituals in which the Siegburg pottery was used.

Besides the dominant stock fish trade concentrated in Bergen, timber, fish oil, herring and hides were the main exports from Norway in the late Middle Ages. These commodities were shipped primarily to the countries around the North Sea. The customs accounts of the eastern English ports from the early fourteenth century are, of course, older than the most intense period of activity in the harbour at Avaldsnes, but they probably indicate the kind of products that also crossed the North Sea in the late Middle Ages. Goods coming from Norway would be mainly stockfish, but also herring, hides, fur, butter, processed timber, whetstones and falcons. The Hanse played a major role in the transportation. ${ }^{56}$ Trade in hides and timber, whetstones and falcons could potentially in one way or the other have involved Notau. As already mentioned the archaeological evidence at Avaldsnes points to the processing of hides and timber, as well as trade in whetstones. We also know that on the southern part of Karmøy, Skudenes, there was a falcon catcher, probably of Dutch origin, around 1520, but when this activity was established is uncertain. ${ }^{57}$

Salted spring herring could have also been the dominant exported article from this part of Norway in the fifteenth century. As mentioned earlier, a DanishNorwegian nobleman in 1532 asked for permission from the commander at Bergenhus castle to sell fish to a merchant from Danzig who was on board a ship at Notau. ${ }^{58}$ Two English ships carrying fish were at the southern end of Karmsund in $1478 .{ }^{59}$ Ten barrels of herring from the Karmsund area was paid in taxes and sent to Bergenhus in the winter of $1518-19 .{ }^{60}$ In 1520 new tax contributions included salted herring, cod and salmon. ${ }^{61}$ Unfortunately, an export of herring would be very difficult to document archaeologically, but it is interesting to note that on the island of Bokn, southeast of Karmsund, there are remains of several hundred small fishermen's huts. The island is clearly marked on the oldest Dutch sea maps. ${ }^{62}$ The date of the huts is unknown, but they are probably medieval or prehistoric. ${ }^{63}$ The finds and the structure of the building complexes indicate large-scale seine fisheries. A coin from Lübeck from about 1392 or a little later was found not far from the huts. ${ }^{64}$

It is typical of the herring fishery that it starts suddenly, is intense during a specific period and then collapses. A good herring period in south-west Norway could historically often last for about sixty to seventy years and then suddenly stop completely. ${ }^{65}$ Such a sequence seems parallel to the history of Notau (a possibly sudden start, an intense activity documented by the deposits in the sea and then a rapid end). South-west Norwegian herring fisheries in the Middle Ages are unfortunately a rather blank page of history, but from the sixteenth and up until the twentieth century these fisheries have been a very important factor in the economic development in this part of the country. There seem to have been a good herring period starting sometime before 1520 that ended c. $1560{ }^{66}$ From the middle of the seventeenth century the catches of herring were once again fairly good in the waters around Karmøy. This continued into the next century, but in 1784 the herring no longer appeared. Their return in 1807 marked the beginning of a herring boom that lasted until 1870. Salted herring was the main export article from this part of Norway and in a top year it is estimated that about a million barrels were produced, most of it exported. The fishing alone involved about 40,000 people. ${ }^{67}$ In the Karmsund area the herring fishery had a strong urbanization tendency.

Interestingly, there is a close connection between such fisheries and boatbuilding. A huge number of boats were built locally during the most intense herring-fishing decades using timber from settlements along the fjords. ${ }^{68}$ A number of other crafts developed to handle the large quantities of herring, for instance, the production of barrels. The herring industry was very unstable compared to the well-known stockfish industry further north. It also needed a more complex organization and higher economic investments. A complicating aspect was the need for huge amounts of high-quality salt. In the late Middle Ages this primarily would have come from the Lüneburg mines, a trade dominated by Lübeck. ${ }^{69}$ The fishing season for spring herring in south-west Norway was from January to March. The sailing season for ships carrying this herring would start in January and end in April. This was, of course, a dangerous time of the year; several medieval sources warn against crossing the North Sea during the winter months. A characteristic of this trade in historical times is that the ships seldom carried anything else than herring. Despite the hazards at sea, people were willing to take the risk if the economic gain was high enough. This might have been the case also in the late Middle Ages. In Catholic Europe the demand for fish and herring was great during the fasting period between Christmas and Easter.

The most intense activity in Notau took place during the most acute part of the late medieval crisis starting c. 1350. This stands in stark contrast to the general situation at the time. The harbour at Avaldsnes could have had some regional importance as a place for exporting goods from the northern parts of Rogaland and southern 
parts of Hordaland. The impact of this locally is perhaps reflected in the fact that 130 farmers on Karmøy could pay $8 \mathrm{~kg}$ of silver and $460 \mathrm{~kg}$ of copper in addition to money (403 mark) as tax in 1519. Copper was usually made available by German merchants. The silver, copper and coins might indicate that local people had been involved in trade with the Hanse. ${ }^{70}$ This amount of wealth on Karmøy, even at a time when Notau had decreased in importance, points towards the existence of a local economy different from the general situation in Norway in the Late Middle Ages.

In the beginning of the sixteenth century, or perhaps some time before, the activity in Notau decreased and the place was abandoned. This coincided with the reduced importance of the Hanse in north European trade. We do not know if some local factors also contributed to the fate of Notau. Perhaps rich herring fisheries in the fifteenth century came to an end, or changes in the regulation of the timber trade could have taken place allowing it to be continued elsewhere in the same region. During the seventeenth century Dutch and Scottish ships sailed directly into the fjords to buy timber from local farmers. ${ }^{71}$

The activity of the Hanse in Norway outside the towns of Bergen, Oslo and Tønsberg is largely unknown. The discovery and investigation of the harbour at Avaldsnes has revealed a very rich archaeological site which clearly played an important role for the Hanse. The remains in the sea, the cultural layers and structures, such as the ballast heaps and jetty foundations are massive in size and undisturbed by modern development, unlike practically any other harbour to which it can be compared. An important result of the investigations carried out so far is the small amount of post-medieval material. Only in the sea outside Gloppe, where local trade took place in the eighteenth and nineteenth centuries, do more recent objects occur in significant numbers. In addition, the seabed in the harbour at Avaldsnes is covered with mud which provides excellent conditions for preservation of archaeological material. The site is thus unique in Norway, and probably also in a European context.

The investigations of the harbour at Avaldsnes were a cooperation between The Maritime Museum of Stavanger, Nordvegen historiesenter, Avaldsnes and Museum of Archaeology, University of Stavanger.

\section{Endnotes}

${ }^{1}$ Opedal 2010.

${ }^{2}$ Skre 2012, 8; Skre 2018.

${ }^{3}$ Skre 2018.

${ }^{4}$ Fyllingsnes 2001a, 20; Fyllingsnes 2001b, 90.
${ }^{5}$ Fyllingsnes 2000; Fyllingsnes 2001a; Fyllingsnes 2004a; Fyllingsnes, this volume; Ersland, this volume.

${ }^{6}$ Lillehammer 1989a, 93; Særheim 1998; Særheim 1999; Særheim 2000; Særheim 2006.

${ }^{7}$ Fyllingsnes 2000; Fyllingsnes 2001a; Fyllingsnes 2001b; Fyllingsnes 2004a; Fyllingsnes, this volume.

${ }^{8}$ Demuth 2001; Grude 1981, 96.

${ }^{9}$ Gaimster 1997; Mehler 2009; Demuth, this volume.

${ }^{10}$ Opedal et al. 2001; Elvestad and Opedal 2001; Elvestad and Opedal 2017.

${ }^{11}$ Særheim 2000, 113.

${ }^{12}$ Krøger and Opedal 2001.

${ }^{13}$ Simonsen 1978.

14 Elvestad and Opedal 2017.

${ }^{15}$ Lillehammer 1989b.

${ }^{16}$ Mehler et al. 2011.

${ }^{17}$ Mehler et. al. 2011.

${ }^{18}$ Fyllingsnes 2008.

${ }^{19}$ Hunt and Bates 2012.

${ }^{20}$ Ibid.

${ }^{21}$ Nitter et al. 2013.

${ }^{22}$ Mehler et al. 2011.

${ }^{23}$ Denham 2012.

${ }^{24}$ Lillehammer 1999; Newland 2012.

${ }^{25}$ Fyllingsnes 2001a, 22.

${ }^{26}$ Ibid.

${ }^{27}$ Nedkvitne 1983, 568.

${ }^{28}$ Fyllingsnes 2001b, 91.

${ }^{29}$ Demuth 2001, 68-74, 99-107; Demuth, this volume.

${ }^{30}$ Fyllingsnes 2001b, 95.

${ }^{31}$ Demuth 2001, 69.

${ }^{32}$ Ibid., 72.

${ }^{33}$ Ibid., 70

${ }^{34}$ Gaimster 1997; Demuth, this volume.

${ }^{35}$ Demuth 2001, 72.

${ }^{36} \mathrm{Ibid}$; ; see also Demuth, this volume, Fig. 7.

${ }^{37}$ Fyllingsnes 2001b.

${ }^{38}$ Myrvoll 1986.

${ }^{39}$ Daly, this volume.

${ }^{40}$ Alopaeus 2003; Alopaeus and Elvestad 2006.

${ }^{41}$ Fyllingsnes 2000; Fyllingsnes 2004a; Fyllingsnes, this volume; Ersland, this volume.

${ }^{42}$ Fyllingsnes 2004a; Fyllingsnes, this volume.

${ }^{43}$ For a presentation of the wreck W5, see Litwin 1980; Litwin 1985.

${ }^{44}$ Auer and Maarleveld 2011.

${ }^{45}$ von Arbin 2012.

${ }^{46}$ Fyllingsnes 2004b.

${ }^{47}$ Stylegar et al., this volume.

${ }^{48}$ Helle 1974, 128.

${ }^{49}$ Helle 1982, 351, 384.

${ }^{50}$ Helle 1974, 129.

${ }^{51}$ Sørheim 2010.

${ }^{52}$ Demuth 2001.

${ }^{53}$ See Ersland, this volume.

${ }^{54}$ Gaimster 1997.

${ }^{55}$ Haugland 2015.

${ }^{56}$ Nielssen 2014, 291; Nedkvitne 1983, 52.

${ }^{57}$ Fyllingsnes 2000, 337-341.

${ }^{58}$ Fyllingsnes 2004a, 7.

${ }^{59}$ Fyllingsnes 2001b.

${ }^{60}$ Ibid. 
${ }^{61}$ Fyllingsnes 2000, 215.

${ }^{62}$ See Fyllingsnes, this volume, for the 1663 map.

${ }^{63}$ Elvestad 2003; see also Magnus 1974.

${ }^{64}$ Letters in Jan Petersen's private archive, Museum Stavanger.

${ }^{65}$ Kolle and Haaland 2006, 133-86, 151.

${ }^{66}$ Fyllingsnes 2004b, 50f., $327 \mathrm{f}$.

${ }^{67}$ Kolle and Haaland 2006, 153.

${ }^{68}$ Ibid., 155.

${ }^{69}$ Nielssen 2014, 225.

${ }^{70}$ Fyllingsnes 2001a, 21.

${ }^{71}$ Lillehammer 1999; Newland 2012.

\section{References}

Alopaeus, H. 2003. Avaldsnes 1 vraket vid Karmøy, Norge. Unpublished report. Stavanger: Stavanger maritime museum.

Alopaeus, H. and Elvestad, E. 2006. Avaldsnesskipet: Et nordisk skip fra Polen?, in A. Kongshavn (ed.), Tormod Torfaus - mellom Vinland og 'Ringenes herre'. Karmøyseminaret 2004, 73-86. Kopervik: Karmøy kommune.

von Arbin, S. 2012. A fifteenth century bulk carrier wrecked off Skaftö, Western Sweden, in N. Günsenin (ed.), Between Continents. Proceedings of the 12 th International Symposium on boat and ship Archaeology, 67- 74. Istanbul: University of Istanbul.

Auer, J. and Maarleveld, T. (eds) 2011. Skjernøysund Wreck 3. Maritime Archaeological Programme. Unpublished report. Odense: University of Southern Denmark.

Demuth, V. 2001. Undersøkelser av keramikken fra Avaldsnes, in E. Elvestad and A. Opedal (eds), Maritimarkeologiske forundersøkelser av middelalderhavna på Avaldsnes, Karmøy, 68-74, 99-107. Arkeologisk museum Stavanger rapport 18. Stavanger: Stavanger Sjøfartsmuseum og Arkeologisk museum.

Denham, S. D. 2012. Animal bones recovered from marine contexts at Avaldsnes. Unpublished report. Stavanger: Stavanger maritime museum.

Elvestad, E. 2003. På leting etter de eldste fiskevœrene. Unpublished report. Stavanger: Stavanger maritime museum.

Elvestad, E. and Opedal, A. (eds) 2001. Maritimarkeologiske forundersøkelser av middelalderhavna på Avaldsnes, Karmøy. Arkeologisk museum Stavanger rapport 18. Stavanger: Stavanger sjøfartsmuseum og Arkeologisk museum.

Elvestad, E. and Opedal, A. (eds) 2017. The Hanseatic Harbour. Reports from the archaeological investigations of the medieval harbour at Avaldsnes, Karmøy. Unpublished report. Stavanger: Stavanger maritime museum.

Fyllingsnes, F. 2000. Karmøys historie, vol. II: Middelalderen. Stavanger: Dreyer.

Fyllingsnes, F. 2001a. Havn og handel i skriftlige kilder, kart og stedsnavn, in E. Elvestad and A. Opedal (eds), Maritim-arkeologiske forundersøkelser av middelalderhavna på Avaldsnes, Karmøy, 19-24. Arkeologisk museum Stavanger rapport 18. Stavanger: Stavanger sjøfartsmuseum og Arkeologisk museum.
Fyllingsnes, F. 2001b. Appendix 1. Katalog over skriftlige kilder og kart, in E. Elvestad and A. Opedal (eds), Maritim-arkeologiske forundersøkelser av middelalderhavna på Avaldsnes, Karmøy, 90-98. Arkeologisk museum Stavanger rapport 18. Stavanger: Stavanger sjøfartsmuseum og Arkeologisk museum.

Fyllingsnes, F. 2004a. Notow - hanseatene si hamn på Avaldsnes. Heimen 41, 3-21.

Fyllingsnes, F. 2004b. Karmøys historie, vol. III: Fra reformasjonen til 1800. Stavanger: Dreyer.

Fyllingsnes, F. 2008. Bygninger på Avaldsnes prestegård. Unpublished report. Institutt for arkeologi, konservering og historie. Oslo: University of Oslo.

Gaimster, D. 1997. German Stoneware 1200-1900. Archaeology and cultural history. London: British Museum Press.

Grude, E. 1981. Skip og havn: Marinarkeologi i Rogaland. Stavanger museum årbok 1981, 83-113.

Haugland, H. 2015. Guilds as a Political Playground: The Ritual of gildedrikk in High and Late Medieval Scandinavia, in L. Jezierski, L. Hermanson, H. J. Orning and T. Småberg (eds), Rituals, Performatives, and Political Order in Northern Europe, c. 650-1350, 321357. Turnhout: Brepols.

Helle, K. 1974. Norge blir en stat 1130-1319. Handbok i Norges historie b. 3. Oslo: Universitetsforlaget.

Helle, K. 1982. Bergen bys historie, vol. I: Kongesete og kjøpstad. Bergen: Universitetsforlaget.

Hunt, C. O. and Bates, J. 2012. Palynology and phytoliths from a fifteenth century layer at Avaldsnes. Unpublished report, Queen's University Belfast and University of Cambridge.

Kolle, N. and Haaland, A. 2006. Den sjøvende landsdelen, in K. Helle (ed.), Vestlandets historie, vol. I, 133-186. Bergen: Vigmostad \& Bjørke.

Krøger, J. F. and Opedal, A. 2001. Søk etter havn og handelssted fra jernalder og middelalder, in E. Elvestad and A. Opedal (eds), Maritim-arkeologiske forundersøkelser av middelalderhavna på Avaldsnes, Karmøy, 25-43. Arkeologisk museum Stavanger rapport 18. Stavanger: Stavanger sjøfartsmuseum og Arkeologisk museum.

Lillehammer, A. 1989a. Hanseatisk kontor på Avaldsnes?, in G. Sør-Reime (ed.), Avaldsnes. Norges eldste kongesete, 93-96. Stavanger: Dreyer.

Lillehammer, A. 1989b. Gjestgjevarstaden Gloppe, in G. Sør-Reime (ed.), Avaldsnes. Norges eldste kongesete, 113-116. Stavanger: Dreyer.

Lillehammer, A. 1999. The Timber Trade and the Ryfylke Farmers 1500-1700, in Timber and trade. Articles on the timber export from the Ryfylke-area to Scotland and Holland in the $16^{\text {th }}$ and $17^{\text {th }}$ century, 6-23. Aksdal: Lokalhistorisk stiftelse.

Litwin, J. 1980. The Copper Wreck. The wreck of a medieval ship raised by the Central Maritime Museum in Gdansk. International Journal of Nautical Archaeology 9(3), 217-225.

Litwin, J. 1985. The Copper ship of Gdansk bay: recent discoveries from the wreck, cargo and site, in J. Haarmann and J. Brackner (eds), The 5th international Congress of Maritime Museums proceedings 1984, 4249. Hamburg: Herman Kampen. 
Magnus, B. 1974. Fisker eller bonde? Unders $ø$ kelser av hustufter på ytterkysten. Viking 38, 68-108.

Mehler, N. 2009. The perception and interpretation of Hanseatic material culture in the North Atlantic: problems and suggestions. Journal of the North Atlantic, special volume 1, 89-108.

Mehler, N., Gardiner, M. and Elvestad, E. 2011. Excavations on Fårøy. Unpublished report. Stavanger Maritime Museum.

Myrvoll, S. 1986. Skien and Telemark - naturressurser, produkter og kontakter i sen vikingtid og tidlig middelalder. Viking 1985/86, 160-180.

Nielssen, A. R. 2014. Markedsretting og nasjonal betydning av fiskeriene 1000-1350, in N. Kolle (ed.), Norges fiskeriog kysthistorie, vol. I, 187-301. Bergen: Fagbokforlaget.

Nedkvitne, A. 1983. Utenrikshandelen fra det vestafjeldske Norge 1100-1600. Unpublished PhD thesis. Bergen: University of Bergen.

Newland, K. C. 2012. To Norroway, to Norroway o'er the farm: sourcing timber for Scotland's seventeenth century building works. Arbok Museum Stavanger 122, 84-117.

Nitter, M., Elvestad, E. and Selsing, L. 2013. Maritime Site Protection and the Fetch Method: an example from Rogaland, Norway. International Journal of Nautical Archaeology 42(1), 87-102.

Opedal, A. 2010. Kongemakt og kongerike. Gravritualer og Avaldsnes-områdets politiske rolle 600-1000. Oslo: Unipub.

Opedal, A., Elvestad, E. and Fyllingsnes, F. 2001. Herskerens havn, hanseatenes havn, handelens havn, in M. S. Vea and H. R. Naley (eds). Fiender og forbundsfeller. Regional kontakt gjennom historien. Karmøyseminaret 1999, 97-121. Kopervik: Karmøy kommune.

Simonsen, A. 1978. Unpublished report. Stavanger: Stavanger maritime museum.

Skre, D. 2012. Utgravningene på Avaldsnes avsluttet. Frá Haug ok heiðni 4, 3-9.

Skre, D. (ed.) 2018. Avaldsnes - A Sea-Kings' Manor in First-Millennium Western Scandinavia. Berlin: de Gruyter.

Særheim, I. 1998. 'Notau ... udi Karmsund'. Hansaens første handelsfaktori i Noreg, in G. Akselberg and J. Bondevik (eds), Ord etter ord. Heidersskrift til Oddvar Nes 27. desember 1998, 242-254. Bergen: Norsk bokreidingslag.

Særheim, I. 1999. Språkkontakt i seinmellomalderen bakgrunn for lokale namn og namneformer, Frá haug ok heiðni 2, 28-33.

Særheim, I. 2000. Notau - innfallsport for hansaen i Noreg?, in Karmøy kommune (ed.), Havn og handel $i$ 1000 år. Karmøyseminaret 1997, 110-116. Stavanger: Dreyer.

Særheim, I. 2006. 'Notau ... udi Karmsund'. Toponyms from southwestern Norway reflecting language contact in medieval times, in E. Brylla, M. Wahlberg and R. Rentenaar (eds), Proceedings of the $21^{\text {st }}$ International Congress of Onomastic Sciences, 289-303. Uppsala: Språk- och folkminnesinstitutet.

Sørheim, H. 2010. Sentralsted, tettsted, knutepunkt, by. Bosetningshierarkier og sentraldannelser på Vestlandet fra jernalder til middelalder. Unpublished PhD thesis. Bergen: University of Bergen. 
Appendix 1. Finds list of underwater test pit no. 1, museum number St-S7499. The pit is approximately $1 \mathrm{~m} \times 1 \mathrm{~m}$.

\begin{tabular}{|c|c|c|c|}
\hline $\begin{array}{l}\text { Depth below } \\
\text { seabed }\end{array}$ & Layer & Material & Description \\
\hline \multirow{7}{*}{$\begin{array}{l}\text { Stray finds } \\
\text { from surface - } \\
10 \mathrm{~cm}\end{array}$} & 1 & Ceramic & Pottery, glazed redware \\
\hline & 1 & Ceramic & Pottery, glazed redware \\
\hline & 1 & Ceramic & Pottery, glazed redware \\
\hline & 1 & Ceramic & Pottery, glazed redware \\
\hline & 1 & Ceramic & Pottery, glazed redware \\
\hline & 1 & Wood & Needle \\
\hline & 1 & Stone & Coal \\
\hline \multirow[t]{11}{*}{$10-20 \mathrm{~cm}$} & 2 & Stone & Cannon ball \\
\hline & 2 & Ceramic & Brick, fragment \\
\hline & 2 & Ceramic & Pottery, lead glazed redware, fragment \\
\hline & 2 & Ceramic & Pottery, lead glazed redware, fragment \\
\hline & 2 & Ceramic & Pottery, lead glazed redware, fragment \\
\hline & 2 & Ceramic & Pottery, lead glazed redware, fragment \\
\hline & 2 & Stone & Ballast? \\
\hline & 2 & Wood & Chopped, fragment \\
\hline & 2 & Wood & Chopped, fragment \\
\hline & 2 & Wood & Chopped, fragment \\
\hline & 2 & Wood & Chopped, fragment \\
\hline \multirow[t]{26}{*}{$20-30 \mathrm{~cm}$} & 2 & Ceramic & Brick, fragment \\
\hline & 2 & Ceramic & Brick, fragment \\
\hline & 2 & Ceramic & Brick, fragment \\
\hline & 2 & Ceramic & Brick, fragment \\
\hline & 2 & Ceramic & Brick, fragment \\
\hline & 2 & Ceramic & Brick, fragment \\
\hline & 2 & Ceramic & Brick, fragment \\
\hline & 2 & Ceramic & Brick, fragment \\
\hline & 2 & Stone & Coal \\
\hline & 2 & Stone & Coal \\
\hline & 2 & Stone & Flint \\
\hline & 2 & Wood & Chopped, fragment \\
\hline & 2 & Wood & Chopped, fragment \\
\hline & 2 & Wood & Chopped, fragment \\
\hline & 2 & Wood & Fragment \\
\hline & 2 & Wood & Fragment \\
\hline & 2 & Wood & Nutshell \\
\hline & 2 & Wood & Nutshell \\
\hline & 2 & Wood & Charcoal \\
\hline & 2 & Wood & Charcoal \\
\hline & 2 & Ceramic & Pottery, lead glazed redware \\
\hline & 2 & Ceramic & Pottery, lead glazed redware \\
\hline & 2 & Ceramic & Pottery, lead glazed redware \\
\hline & 2 & Ceramic & Pottery, lead glazed redware \\
\hline & 2 & Ceramic & Pottery \\
\hline & 2 & Organic & Rope \\
\hline
\end{tabular}

\begin{tabular}{|c|c|c|c|}
\hline Depth below & Layer & Material & Description \\
\hline & 2 & Leather & Cut, fragment \\
\hline & 2 & Leather & Cut, fragment \\
\hline & 2 & Leather & Cut, fragment \\
\hline & 2 & Leather & Needlemarks \\
\hline \multirow[t]{33}{*}{$30-45 \mathrm{~cm}$} & 2 & Wood & Nut, hazel \\
\hline & 2 & Wood & Nut, hazel \\
\hline & 2 & Wood & Charcoal \\
\hline & 2 & Leather & Cut, fragment \\
\hline & 2 & Leather & Cut, fragment \\
\hline & 2 & Leather & Cut, fragment \\
\hline & 2 & Leather & Cut, fragment \\
\hline & 2 & Wood & Cut, fragment \\
\hline & 2 & Wood & Cut, fragment \\
\hline & 2 & Wood & Cut, fragment \\
\hline & 2 & Wood & Cut, fragment \\
\hline & 2 & Wood & Cut, fragment \\
\hline & 2 & Wood & Cut, fragment \\
\hline & 2 & Wood & Cut, fragment \\
\hline & 2 & Wood & Cut, fragment \\
\hline & 2 & Wood & Cut, fragment \\
\hline & 2 & Wood & Cut, fragment \\
\hline & 2 & Wood & Cut, fragment \\
\hline & 2 & Wood & Cut, fragment \\
\hline & 2 & Wood & Cut, fragment \\
\hline & 2 & Wood & Cut, fragment \\
\hline & 2 & Wood & Cut, fragment \\
\hline & 2 & Wood & Cut, fragment \\
\hline & 2 & Wood & Bark \\
\hline & 2 & Ceramic & Brick \\
\hline & 2 & Ceramic & Lead glazed redware \\
\hline & 2 & Wood & Needle \\
\hline & 2 & Wood & \\
\hline & 2 & Wood & \\
\hline & 2 & Wood & Cut, fragment \\
\hline & 2 & Leather & Cut, fragment \\
\hline & 2 & Leather & Needle marks \\
\hline & 2 & Stone & Flint \\
\hline \multirow[t]{6}{*}{$65-85 \mathrm{~cm}$} & 4 & Ceramic & Brick \\
\hline & 4 & Organic & Textile \\
\hline & 4 & Wood & Charcoal \\
\hline & 4 & Wood & Cut, fragment \\
\hline & 4 & Wood & Cut, fragment \\
\hline & 4 & Wood & Cut, fragment \\
\hline
\end{tabular}

